\title{
Közös szülőség a válás után: szakirodalmi áttekintés
}

\author{
PILINSZKI ATTILA ${ }^{1 *}$ - GYETVAI ANNA² \\ ${ }^{1}$ Semmelweis Egyetem, Egészségügyi Közszolgálati Kar, \\ Mentálhigiéné Intézet, Budapest, Magyarország \\ ${ }^{2}$ Semmelweis Egyetem, Mentális Egészségtudományok Doktori Iskola, Budapest, \\ Magyarország
}

(Beérkezett: 2020. december 9.; elfogadva: 2021. március 25.)

Tanulmányunk célja áttekintést nyújtani a válás utáni közös szülőségre, a szülők együttmúködésére és konfliktusaira vonatkozó főbb kutatási eredményekről. A közös szülőség fogalma a szülók közötti interakciókat, kapcsolatot jelenti, amit a válást követően is szükséges fenntartani. Tanulmányunkban egyrészt kitérünk a közös szülőség egyes aspektusaira (szülői kommunikáció, egymás támogatása-aláásása, konfliktusok és konfliktuskezelés), másrészt a vonatkozó vizsgálatokban leggyakrabban megjelenó háttérváltozókra (válási folyamat, elhelyezés típusa). A válás következményei, az új helyzethez való alkalmazkodás sikeressége mind a szülők, mind a gyerekek részéről jelentős társadalmi fontossággal bír, ennek ellenére a válás utáni közös szülőség témája csak egy-egy hazai publikációban jelenik meg. Jelen tanulmánnyal célunk ennek a hiánynak a pótlása, valamint a kérdéskör hazai kutatásának inicializálása. A vizsgált szakirodalom alapján elmondható, hogy a párkapcsolat felbomlása után kiemelten fontos egy új egyensúlyi állapot kialakítása, mivel a közös szülőség minősége összefüggést mutat a gyermekek és a felnőttek jóllétével is. A vonatkozó empirikus szakirodalom egy része azokra a preventív képzési programokra irányul, amelyek a válás utáni közös szülőség minőségének fejlesztését túzték ki célul. Említést teszünk ezért több ilyen programról, röviden ismertetve a sajátosságaikat és a kapcsolatos empirikus eredményeket. Következtetésként elmondható, hogy a válást követő közös szülőség komplex témaköre és a szülők sokszor eltérő narratívája miatt olyan diádikus kutatási megközelítés választása indokolt, amellyel ez az összetettség megragadható. Felhívjuk továbbá a figyelmet arra, hogy hazánkban hiányoznak az elvált szülőknek kínált edukációs programok, pedig a szülők és gyermekek jóllétének érdekében fontos lenne ezek kifejlesztése, hatékonyságuk vizsgálata és a megfelelő hatékonyságú programok rendszerszintú elterjesztése.

Kulcsszavak: közös szülőség, válás, konfliktus, együttmúködés, gyermekek jólléte

\section{Bevezetés}

A szülői együttmúködés, a közös nevelés, a közös szülőség a családi múködés egy rendkívül fontos aspektusa. A közös szülőség fogalma a szülők közötti kapcsolatra és interakciókra, különösen a szülői alrendszer múködésé-

\footnotetext{
* Levelező szerző: Dr. Pilinszki Attila, Egészségügyi Közszolgálati Kar, Mentálhigiéné Intézet, 1089 Budapest, Nagyvárad tér 4. E-mail: pilinszki.attila@public.semmelweis-univ.hu
} 
re fókuszál. Feinberg definíciója szerint „a közös szülőség arra a módra vonatkozik, ahogyan a szülők és/vagy más szülő figurák a szülői szerepükben egymáshoz kapcsolódnak" (Feinberg, 2003, 96. o.). A téma vizsgálata során hasonló tartalommal a közös szülőséget több kapcsolódó szakkifejezéssel írták el, mint például a "szülői partnerkapcsolat” (parental partnerships, Floyd \& Zmich, 1991) vagy „szülői szövetség” (parental alliance, Becher és mtsai, 2019; Lamela \& Figueiredo, 2011). A hazai családterápiás gyakorlatban is elterjedt kifejezés a szülőtársi kapcsolat, ugyanakkor az angolul coparenting szóval jelzett konstruktum ennél tágabb jelentéstartalommal bír, és arra a módra vonatkozik, ahogy a szülőtársak egymással kapcsolatban és interakcióban állnak. A közös szülőség legtöbbször egy diádikus kapcsolatot jelent a gyermek szülei között, de akár többszereplős felállásról is beszélhetünk, ahol a gyermek nevelésében részt vevő személyekről (szülők, nagyszülók, nevelószülők) van szó.

A közös szülőség kérdésköre az elvált családokban is kiemelt kérdés, hiszen a szülői felelősség és feladatok a válással nem szúnnek meg, és a szülők együttmúködése mind a felnőttek, mind pedig a gyermek(ek) jóllétét befolyásolja (Adamsons \& Johnson, 2013; Lamela, Figueiredo, Bastos, \& Feinberg, 2016). Általánosságban elmondható, hogy az elvált szülők gyermekeinek rosszabb az egészségi állapota és társadalmi, szociális hátrányokat is tapasztalnak (Fransson, Turunen, Hjern, Östberg, \& Bergström, 2016). A családfelbomlások száma hazánkban és nemzetközi szinten továbbra is jelentősnek mondható, a gyermekek számottevő része átéli a szülei különválását (Fransson és mtsai, 2016). A 2017-ben elváltak 31\%-ának egy, 19\%-ának kettő, 5\%-ának pedig három vagy több gyermeke volt (KSH, 2019). Különösen fontos kérdés ezért, hogy a szülők hogyan maradnak szülők a válást, különválást követően; hogyan sikerül egy új egyensúlyi állapotot kialakítaniuk, amiben továbbra is családként tudnak funkcionálni. A közös szülőség válás utáni kialakítását számos tényező befolyásolhatja és ezeknek alapját a korábbi kapcsolat, valamint a válási folyamat sajátosságai adják.

Jelen tanulmányunkban az elmúlt két évtized válás utáni szülőségre vonatkozó kutatásait tekintettük át, megvizsgálva a felmerült témákat, valamint az ezekhez kapcsolódó méróeszközöket. Szakirodalmi kutatásunk során a Scopus, a PubMed és a Google Scholar adatbázisaiban kerestünk tanulmányokat a "divorce”, ,partnership dissolution", ,parenting", "coparenting", , "parenting alliance" és „interparental conflict” keresőkifejezésekkel, elsősorban az utóbbi 20 év tanulmányaira fókuszálva. A közös szülőség témaköréről ezzel igyekszünk széles, bár nem teljes körú áttekintést nyújtani.

Az 1. ábrán láthatóak azok a főbb témák, amelyekkel a vizsgált cikkekben foglalkoztak. A válás utáni szülőség címszó alatt azokat az altémákat (együttmúködés, támogatás/aláásás, kommunikáció, konfliktusok, készség 
a közös szülőségre) soroltuk fel, amelyek a közös szülőség egyes dimenzióit jelenthetik, ahogy a közös szülőség különböző mérőeszközeiben ez meg is jelenik (Ahrons, 1981; Feinberg, Brown, \& Kan, 2012). A következőkben ezeket és a kapcsolódó (jellemzően magyarázó változóként használt, a válási folyamatra, a gyermek elhelyezésének típusára vonatkozó, valamint a függó változóként megjelenő gyermekek és szülők jólléte, szülő-gyermek kapcsolat) témákat tárgyaljuk. A tanulmány további részében először az 1. ábrán a keretezett részben feltüntetett fogalmakkal (a közös szülőség különböző aspektusaival) foglalkozunk. Ezt követően a válástörténet és a gyermek(ek) elhelyezésének témakörével folytatjuk, amelyek nagy hangsúllyal jelentek meg a vizsgált szakirodalomban. A szülők és gyermekek jóllétére, valamint a szülő-gyerek kapcsolatra vonatkozó kérdésekkel nem külön alfejezetben foglalkozunk, hanem az egyes témáknál emeljük ki az ezekre vonatkozó eredményeket. Végül azokról a prevenciós programokról és különböző beavatkozási módszerekról adunk rövid áttekintést, amelyek a közös szülőség általunk vizsgált szakirodalmában hangsúlyosabban megjelentek.

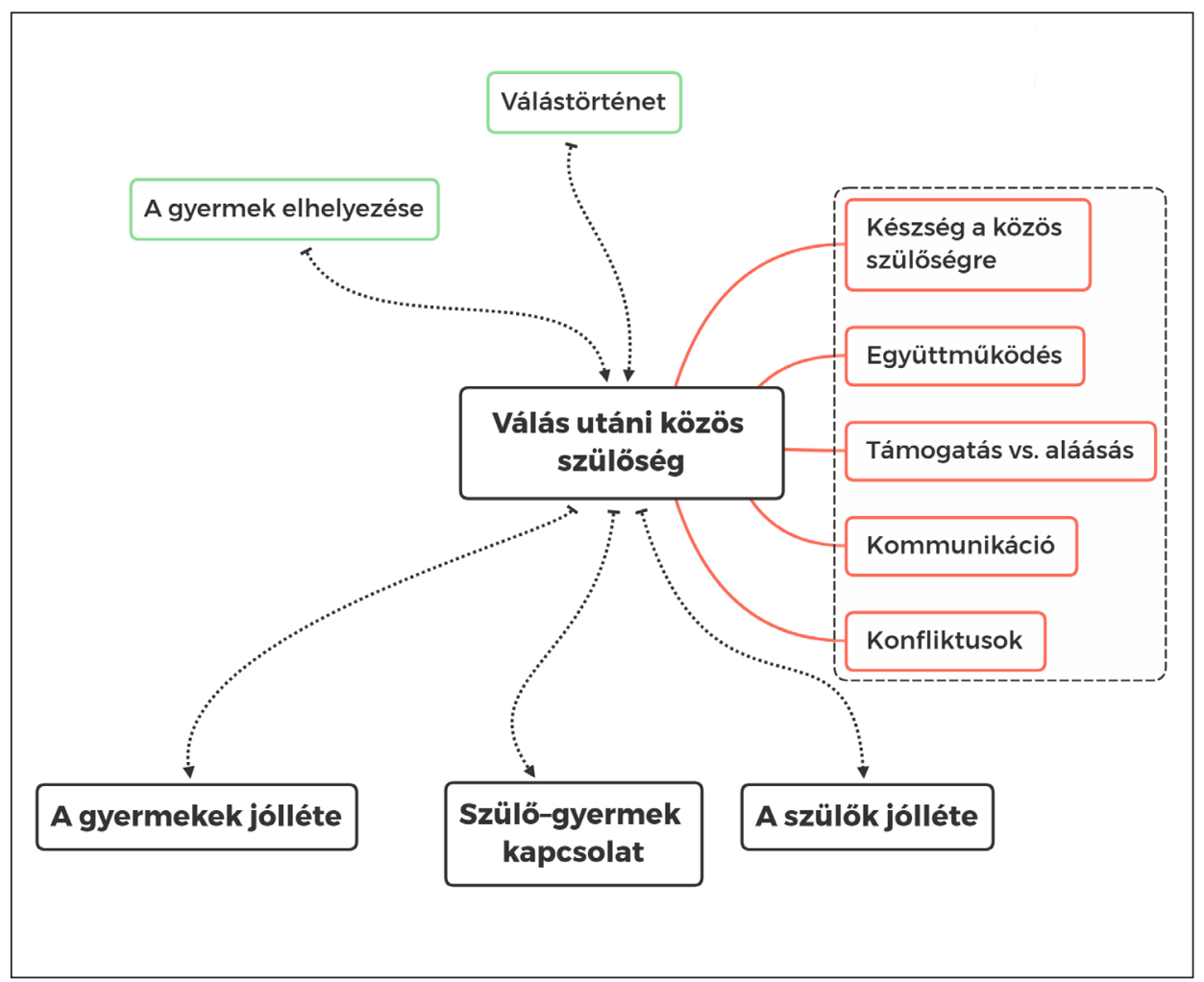

1. ábra. A válás utáni szülőséggel kapcsolatban megjelenő témakörök 


\section{A közös szülőség és egyes aspektusai}

McHale, Kuersten-Hogan és Rao (2004) a közös szülőség három lényegi öszszetevőjét említik: a szülők közötti szolidaritás és egymás támogatásának mértékét; a közös szülói törekvésekben a nézeteltérések és ellentétek mértékét; valamint a felek részvételének mértékét a gyermek gondozásában, nevelésében. Több tanulmányban a válás utáni közös szülőség típusai is bemutatásra kerültek, s ezeket a tipológiákat jellemzően a kommunikációs stílust/gyakorlatot, valamint az együttmúködést és a konfliktusok szintjét mérő változók elemzésével alakították ki (Ahrons \& Miller, 1993; Amato, Kane, \& James, 2011; Beckmeyer, Markham, \& Troilo, 2019; Markham \& Coleman, 2012).

Vannak kutatók (Buchanan, Maccoby, \& Dornbusch, 1991; Mullett \& Stolberg, 1999), akik a szülők közötti konfliktusokon belül kiemelik a trianguláció mértékét, mint a közös szülőség jellemzőjét, hiszen ennek nagy jelentősége van a gyermek jóllétének alakulásában. A válás utáni szülőii kapcsolat további indikátoraként emelik még ki a szülői kommunikációt (Jamison, Coleman, Ganong, \& Feistman, 2014) is. Ezek alapján is jól látszik, hogy a közös szülőség egy többdimenziós konstruktum, ami a gyerek(ek) neveléséhez kapcsolódó, szülők közötti kapcsolati dinamika komplex rendszerét írja le. A közös szülőségre vonatkozó elméleti keretében Feinberg (2003) négy fő területet határoz meg: a gyerekneveléssel kapcsolatos egyetértést; a másik szülőségének támogatását/aláásását; a gyermek gondozásával, nevelésével kapcsolatos munkamegosztást; valamint a családi dinamika közös kezelését. Ez utóbbi arra vonatkozik, hogyan és mit kommunikálnak a gyermek felé a másik szülőről, mennyire kerülik vagy engedik a szülő-gyermek koalíciókat. Ennek a területnek fontos eleme a gyermek szülői konfliktusoknak való kitettsége.

\subsection{Kommunikáció}

A válást követő közös szülőség melletti elköteleződés folyamatának elemzéséhez jó értelmezési keretet nyújt Watzlawick (2011) kommunikációs elmélete. Watzlawick abból a feltevésből indul ki, hogy minden viselkedés kommunikáció és a kommunikáció egy interaktív folyamat. A felek kommunikációjának megváltoztatása segítheti a szülők válásukra és egymásra vonatkozó percepciójának átalakulását. Az elvált szülők gyakran adnak maladaptív válaszreakciót a válási stresszre, s amikor a másik féltől megtámadva érzik magukat, védekezési folyamat indul be. A védekezés pedig könnyen agresszióként interpretálható, ami a konfliktus eszkalációjához vezet. Watzlawick (2011) szerint a probléma gyakran azzal indul, amikor a fe- 
lek félreértelmezik a másik kommunikációját az információk hiánya vagy a korábbi tapasztalatokból származó előzetes szürők miatt. A szülők gyakran tudatában sincsenek, hogy félreértelmezik a másik üzeneteit és következetesen aszerint reagálnak, amit a másik fél nem tud megfelelően értelmezni. Moore (2014) felosztása szerint a vitahelyzetek egyik fő típusa az információs jellegú konfliktus. Ezek között említhetô az információhiány, a túl sok információ és az információk eltérő értelmezése is. Az üzenetek összehangolása, megosztása és mederbe terelése csökkenti a felek közötti információs rést és segít kilépni a lefelé tartó kommunikációs spirálból.

Több tanulmányban is rámutattak arra, hogy a kommunikáció gyakorisága mellett (vagy akár előtt) kiemelten fontos annak témája, fókusza is. Miről kommunikálnak a szülők? A gyermekről és a szülőség kérdéseiről vagy más területekról is? Jamison és munkatársai (2014) elvált anyákkal és apákkal végzett interjús vizsgálatukban $(n=47)$ azt a mintázatot találták, hogy a reziliens közös szülőség (ami kevés konfliktussal és eredményes közös döntéshozatallal jár) megjelenése együtt jár a gyermekek jóllétének és szükségleteinek gyakori és explicit megfogalmazásával. Erre utalt a használt nyelvezet is: akik a gyermek szükségleteit helyezték fókuszba, jellemzően a „mi” személyes névmást használták, amikor magukról és expartnerükról beszéltek, míg azok a szülók, akik a válásra és egymásra fókuszáltak, az „én”-nyelvet használták. Amikor viszont a szülők a korábbi partnerükkel való kapcsolatuk hiányosságaiba merülnek el, kihívást jelent a számukra fókuszban tartani a gyermek(ek) legjobb érdekét (Oppenheim \& KorenKarie, 2012). A perspektivikus és intencionális kommunikáció, azaz annak megtervezése, hogy mikor és miról beszélnek a szülők egymással, segíti a konfliktusok elkerülését (Barth, 2016). A fókusz megtartása segíti a feleket a közös szülőség pozitív megvalósításában. A közös szülőség és a szülők iskolai bevonódásának vizsgálata során látszik, hogy az iskoláskorú gyermeket nevelő családoknál a kommunikáció új lehetőségei kerülnek előtérbe: hogyan tudnak a gyermekük életébe involválódni, különösen az iskola területén. Az iskolával kapcsolatos kommunikáció és támogatás révén az apák jobban a családi rendszer részének érezhetik magukat és tisztább szerep alakul ki a gyermekük iskolai életébe való bevonódásával kapcsolatosan (Berryhill, 2017). Ezen eredmények mellett Finzi-Dottan és Cohen (2014) a szülői kommunikáció nemi sajátosságait is vizsgáló kutatásában $(n=123$ nő, 94 férfi) szintén azt találta, hogy az anyák inkább elkötelezettnek érzik magukat a gyermekfókuszú kommunikáció és a másik támogatása mellett, mint az apák. Feltehetóen itt a különbségek hátterében elsősorban nem férfinői sajátosságok, hanem a gyermekelhelyezés jellemzői és más tényezők állnak.

Több kutatás eredménye is rámutatott arra, hogy az elvált szülők közötti negatív, nem együttmúködő kommunikáció összefügg a gyermek(ek) jóllé- 
tével, hiszen a gyermek szükségletei kevesebb figyelmet kapnak, növekszik a szorongásuk, valamint gyakrabban és intenzívebben merül fel bennük a lojalitáskonfliktus is (Altenhofen, Biringen, \& Mergler, 2008; Bastaits \& Mortelmans, 2016; Beckmeyer, Coleman, \& Ganong, 2014). A triangulációs kommunikáció és a szülők közötti feloldatlan ellenségesség az elidegenítő viselkedés alapjaként szolgálhat (Mayes \& Moliter-Siegl, 1999, id. Altenhofen és mtsai, 2008). A másik pólusról Barth (2016) kvalitatív vizsgálatában $(n=13)$ a szülők azt állították, hogy „egy szó lenyelése" vagy a „késleltetett válaszadás” segítette a viták megelőzését és javította a közös szülői kapcsolatot. A nevelési sikerek és kudarcok - mi az, ami múködik a gyermeknél és mi az, ami nem - egymással való megosztása hozzájárul a konzisztens szülőséghez, ami segíti a gyermek(ek) alkalmazkodását a válás utáni helyzethez (Barth, 2016). Bergström, Sarkadi, Hjern és Fransson (2019) is felhívják a figyelmet arra, hogy a gyermek fejlődése érdekében mindenképpen szükséges kommunikálni a mindennapi rutinok összehangolásáról és a gyermeknevelés kérdéseiról (pl. a hiszti kezelése). A szülők közötti kommunikáció a gyerektől való elszakadás érzetét is csökkentheti. A gyakori kommunikáció a szülőtárssal segíti, hogy akkor is jelen legyen a gyermek életében, amikor az a másik szülóvel van (Bergström és mtsai, 2019).

Fontos tényező a kommunikációs csatornák kérdése is. A válás után a szülőknek rendszeresen szükséges kommunikálniuk a gyermekek mindennapi szükségleteiről. A szülők különböző infokommunikációs technikákat használnak, ami alternatívája lehet ugyan a személyes és telefonos csatornának, azonban több félreértésre is lehetóséget adhat (a nonverbális kommunikáció és az azonnali reagálás, korrekció lehetőségének hiánya csökkentheti az üzenetek érthetőségét). A válással jelentősen megváltozhat a szinkron és aszinkron kommunikáció aránya, és olyan kommunikációs formák válhatnak dominánssá, mint az e-mail, az SMS, a Facebook vagy más, azonnali üzenetküldő szolgáltatás, megosztott naptár, képmegosztás (Dworkin, 2016; Ganong, Coleman, Feistman, Jamison, \& Stafford Markham, 2012; McDaniel, Galovan, Cravens, \& Drouin, 2018). Sok szülő előnyben részesíti a kommunikáció írott formáját, ami egyrészt jól követhető, másrészt a felek megfontoltabban és tárgyilagosabban kommunikálnak így, mint élő szóban. Az angolszász országokban megjelentek az elvált szülők közötti kommunikációt segító célszoftverek is (Sanderson, 2018).

Jamison és munkatársai (2014) eredményei azt jelzik, hogy hatékonyabb a kommunikáció, ha egyik, vagy mindkét fél elkerüli a mérgezó témákat, illetve ha nem tudja elkerülni, akkor hatékony kommunikációs módszereket választ (nyugodt hangnem, infokommunikációs technikák), a problémákat üzleti stílusban kezeli, azaz a probléma és annak megoldása van a fókuszban és nem merül bele egyéb személyes dolgokba, valamint rugalmas az interakciók és a döntéshozatal során. 


\subsection{Konfliktus}

Minden kapcsolat természetes velejárói a konfliktusok, így a válófélben lévő vagy elvált szülőknél még a konfliktusok magasabb szintje is normálisnak tekinthetó. Mindemellett fontos kiemelni, hogy a kutatások eredményei konzisztensen alátámasztják, hogy a gyakori és intenzív konfliktusok és a rossz minőségú közös szülőség a gyermekek válási helyzethez való problémás alkalmazkodásának rizikótényezői (Amato, 2010; Becher és mtsai, 2019; Fabricius, Sokol, Diaz, \& Braver, 2012; Grych, Seid, \& Fincham, 1992; Lansford, 2009). Az elváltak körében végzett kutatások eredményei felhívják a figyelmet arra, hogy a konfliktusok magasabb szintje számos káros hatással jár együtt, beleértve az alacsonyabb jóllétet (Amato \& Gilbreth, 1999; Lamela \& Figueiredo, 2016), valamint a depresszió és a szorongás magasabb szintjét (Symoens, Colman, \& Bracke, 2014). A szülők konfliktusai a gyermekek pszichés jóllétével és a szülő-gyermek kapcsolat alakulásával is szoros asszociációt mutatnak (Fabricius \& Luecken, 2007; Vanassche, Sodermans, Matthijs, \& Swicegood, 2013). Sőt, a szülői konfliktus moderálja a szülő-gyerek kapcsolat és a gyermek jellemzőinek összefüggését, azaz nem elég egyedül megtenni mindent szülőként (Becher és mtsai, 2019).

A szülők közötti konfliktus egy többdimenziós konstruktum, amibe Smyth és Moloney (2019) leírása alapján beletartoznak 1. a nézeteltérések témái (pl. a kapcsolattartás, a gyermektartási díj, a szülői felügyelet kérdése), 2. a konfliktuskezelés módja, ahogyan a felek megpróbálják megoldani a vitákat (informális stratégiák, pl. elkerülés, alkalmazkodás, fizikai vagy intellektuális erőszak; és formálisabb eszközök is, pl. mediáció, hivatalok bevonása), valamint 3 . az attitúddimenzió, azaz a nyílt vagy rejtett ellenségeskedés és a kommunikáció érzelmi színezete.

A konfliktusos témák között rendszerint megjelennek a szülói felügyeleti jog gyakorlása, a gyermektartás összege, a különélő szülő és a gyermek(ek) közötti kapcsolattartás (ezek többek között egy házassági bontóper járulékos kérdései), de olyan témák is jellemzőek, amelyek a szülők kommunikációjára, illetve együttmúködésére vonatkoznak. Bergman és Rejmer (2017) 33 esetet vizsgáló felmérésükben külön kategorizálták az érdekkonfliktusokra (pl. a gyermekkel töltött idő megosztása, anyagiak, a gyermek lakhelye) és értékkonfliktusokra (pl. a gyermekgondozási képesség hiánya, addikciók, erőszak/fenyegetés/bántalmazás, együttmúködési nehézségek) vonatkozó témákat. Szinte mindegyik esetben említették a felek az értékkonfliktusokat, viszont a válaszadók valamennyivel több mint egyharmada jelzett valamilyen érdekkonfliktust (is). Az értékkonfliktusok kapcsán a leggyakrabban a szülői képességeket kérdőjelezték meg, míg az érdekkonfliktusok közül a legtöbben a gyermekkel töltött időt és az információhiányt említették. Bonach és munkatársai (2005) nyolc konfliktusterület közül csak kettóben találtak nemi különbségeket a vizsgálatukban: a férfiak gyakrab- 
ban jelezték a kapcsolattartással összefüggő vitákat, a nők pedig több olyan konfliktusról számoltak be, ami a szerhasználattal volt kapcsolatos.

A konfliktusok gyakorisága és intenzitása a kapcsolatok minőségének fontos indikátora. A konfliktus lendületet adhat a válásnak és segíthet a végső döntés meghozatalában (Gigy \& Kelly, 1992). A kapcsolat felbomlásánál a felek a társadalmi cserekapcsolat elmélete szerint mérlegelik a kapcsolatból származó nyereségeket és a feszültségeket. A válási döntés meghozatalát követően azonban nehéz megtalálni az együttmúködés egyensúlyát, hiszen a közös kapcsolat sikertelenségének élménye maga is konfliktusokat generál (Becher és mtsai, 2019). A szülők a válást követően gyakran kerülnek konfliktusba, mivel még nem definiálták újra a kapcsolati határokat (Madden-Derdich, Leonard, \& Christopher, 1999). Bár a szülói konfliktusok a párkapcsolat megszakadása előtt, a válás közben és az azt követó két évben jellemzően jelen vannak, az idő múlásával általában kialakul egy új egyensúlyi állapot és a viták gyakorisága csökken (Kelly, 2012). Maccoby és munkatársai (1990) meghatározó tanulmányukban a válaszadók 75\%-ánál enyhe vagy elhanyagolható, 10\%-ánál jelentős, további 15\%-ánál pedig intenzív konfliktusokról számolnak be. Egy nagymintás $(n=9028)$ ausztrál longitudinális vizsgálat (Qu, Weston, Moloney, Kaspiew, \& Dunstan, 2014) mindhárom mérési időpontjában az elvált szülők 58-62\%-a számolt be barátságos-együttmúködő kapcsolatról, 19-27\%-a jelzett távolságtartó kapcsolatot, 11-14\%-a mondta, hogy sok konfliktusuk van, míg 4-5\%-a félelemteliként jellemezte a kapcsolatot. Nemi különbségeket csak a félelemmel teli kategóriában találtak, ahol a nők kétszer annyian jelezték ezt, mint a férfiak. A vizsgálat longitudinális jellege lehetőséget adott az idóbeli változás követésére is. A kapcsolat típusa a szülók felénél nem változott az 5 éves periódusban: $40 \%$ pozitív, 5\% távolságtartó és $4 \%$ maradt negatív. A résztvevők megközelítőleg ugyanakkora arányban (18\%) jeleztek pozitív és negatív irányú változást. A válaszadók további 14\%-ánál a besorolás a három időpontban ingadozott. Hald és munkatársai (2020) elvált szülőket vizsgáló kutatásukban $(n=1144)$ azt találták, hogy a nóknek alacsonyabb az átlagos konfliktuspontszáma (egy 9 tételből álló kérdéssorral mérték fel a válás körüli konfliktusok több dimenzióját, mint például egyes vitatémák gyakorisága, a konfliktuskezelés, az attitúd, az érzelmi környezet biztonságossága), és ennek varianciáját több tényező magyarázza. A konfliktuspontszám növekedésének szignifikáns előrejelzőjének bizonyult a magasabb életkor, a korábbi párkapcsolatban megjelenő erőszak és hútlenség, illetve ha a korábbi partnernek új párkapcsolata volt. A férfiaknál a konfliktusok szintje leginkább azzal függött össze, hogy ki kezdeményezte a válást. A korábbi tanulmányok (Langlais, Anderson, \& Greene, 2016; Symoens és mtsai, 2014) eredményei azt jelzik, hogy az új partner jelenléte növeli a pszichológiai és anyagi jóllétet is. Hald és munkatársai (2020) vizsgálatában azonban 
akkor bizonyult a legmagasabbnak a konfliktus szintje, ha csak a férfinak van új partnere . Egy másik kutatásban 176 elvált floridai szülőt megkérdezve azt találták, hogy a válási egyezséggel/végzéssel való elégedettség csökkenti a nyílt és rejtett konfliktusokat, a gyermek életkorának emelkedésével viszont gyakoribbnak élték meg a rejtett konfliktusokat (Petren, Ferraro, Davis, \& Pasley, 2017).

A konfliktusok gyakoriságához és intenzitásához kapcsolódik a konfliktusos válás (high conflict divorce) kifejezés, ami az előző évtizedekben egyre többször jelent meg a tudományos és szakmai kommunikációban. A konfliktusos válás definíciói és elméleti megközelítései némiképp változatosak (Haddad, Phillips, \& Bone, 2016; Smyth \& Moloney, 2019). A konfliktusos válások arányát egyéb tényezők mellett az egyes vizsgálatokban befolyásolja az adott kutatásban megcélzott populáció, a mérőeszköz és a válás óta eltelt idő. A konfliktusos válás főbb jellemzőjeként Anderson és munkatársai (2011) az átható negatív interakciókat, illetve az ellenséges, érzelmileg instabil társas környezetet emelték ki. Mások a két évnél tovább tartó válási folyamatot jelölik a fogalommal, amit nagyfokú harag, ellenségeskedés, bizalmatlanság és nehezített kommunikáció jellemez (Cohen \& Levite, 2012). A konfliktusos válások azonosítása klinikai, jogi és társadalmi fontossággal is bír. Egyéni szinten a leghátrányosabban a nagyon konfliktusos válás befolyásolja a szülők és a gyermek(ek) pszichológiai jellemzőit. Társadalmi szempontból a nagyon konfliktusos válások hosszabb, komplexebb és drágább beavatkozásokat kívánnak a hatóságoktól, mint a kevesebb konfliktussal bíró válások. Ezek alapján, a potenciálisan konfliktusos válások korai azonosítása lehetóvé tesz olyan beavatkozásokat, amelyek megelőzhetik a konfliktus későbbi eszkalációját és segítik a felek konstruktív konfliktuskezelését. Ezzel a hivatalok és segítő szolgáltatások is időt és erőforrásokat spórolhatnak meg (Hald és mtsai, 2020). A beavatkozás megfelelő módjának megválasztásához kiváló elméleti keretet nyújt Glasl (1999) modellje a konfliktusok eszkalációjáról, amely a konfliktusok kilenc szintjét írja le (a feszültségtől a szakadékig), három szakaszra osztva. Amikor a felek elérnek a harmadik fázisba, már elfogadható a saját veszteség is, ha a másik nagyobbat veszít. A folyamat első harmadában a közvetlen tárgyalás, a másodikban a mediáció, a harmadikban pedig a hatósági intézkedések jelentik az adekvát beavatkozást.

Visser és munkatársai (2017) a természetes támaszok és a megbocsátás kapcsolatát vizsgálták a válást követő időszakban. Tanulmányukban kiemelték, hogy a késóbbi konfliktusok tekintetében kulcsszerepe van a megbocsátásnak. A felek közötti bizalmi sérülések fontos stresszorok a válás előtt, közben és utána, hozzájárulva a közös szülői konfliktusok fenntartásához és eszkalációjához. E szerzők a korábbi kutatások (Bonach, 2005; Bonach \& Sales, 2002) eredményeihez hasonlóan arra jutottak, hogy a meg- 
bocsátás és a párkapcsolat felbomlásának elfogadása az egyik legerősebb előrejelzője a hosszan tartó közös szülőség jobb minőségének és a konfliktusok alacsonyabb gyakoriságának. Felhívták arra is a figyelmet, hogy a kapcsolathálózat tagjai nehezebben bocsátanak meg az expartnernek, mint maguk a felek, és rendszeresen témává teszik az elszenvedett sérelmeket, negatívan beszélnek a volt partnerról, ami megnehezíti a szülők kapcsolatának új alapokra helyezését.

A szülők konfliktusára adott gyermeki válaszok, illetve a gyermekek bevonása a konfliktusba további réteget adnak az eddigi komplex képhez. A triangulációs múködés - ahogyan erre már korábban is utaltunk - megnyilvánulhat egyrészt abban, ahogy a gyermek előtt kommunikálnak a szülők, illetve ahogy a gyermekkel beszélnek a másik szülőről. A különböző közös szülőségre vonatkozó mérőeszközökben külön alskálaként jelenik meg például a gyermek konfliktusoknak való kitettsége (Feinberg és mtsai, 2012; Margolin, Gordis, \& John, 2001). A trianguláció leírható a szülői alrendszer problémáinak a gyermeki alrendszer felé történő továbbgyûrúződésével. Ennek során előfordulhat, hogy a szülők a gyermek lojalitásáért versengenek, esetleg elidegenítik a gyermeket a másik szülótól. Ez a fajta negatív családi múködés túlterheli a gyermeket és elveszi a stabilitás és biztonság érzetét (Lau, 2017).

A gyermekek válaszának egyik jellemző módja az ún. „kaméleon múködés" (Garber, 2014), azaz a gyermek azt mondja az éppen jelen lévő szülőjének, amit az hallani szeretne. Egy másik lehetőség, hogy állást foglal az egyik mellett (általában, akivel a több időt tölti), a másiktól pedig eltávolodik. Sok gyermek csendesen befelé fordul, megpróbál láthatatlan maradni. Mindhárom esetben erősen megjelenik a lojalitáskonfliktus, ami belső feszültséggel jár és csökkenti a gyermek jóllétét (Smyth \& Moloney, 2019). A gyermekek reakciója nagymértékben függ attól, hogy mennyire vannak kitéve a szülők vitáinak. Jellemző-e, hogy szem- és/vagy fültanúi a veszekedéseknek? Használják-e a gyermekeket „postás”-ként a szülők, és velük üzennek egymásnak (direkt vagy indirekt módon)? Megosztják-e a gyermekkel a másik szülővel kapcsolatos negatív gondolataikat, érzéseiket? Buchanan és munkatársai (1991) klasszikusnak tekinthető tanulmányukban vizsgálták az elvált szülők konfliktusait és kamasz gyermekeik részvételét ezekben. A konfliktusos válásoknál gyakrabban érezték úgy a fiatalok, hogy "középre kerültek" (caught in the middle). Ennek az érzete szoros összefüggést mutatott a gyermekek magasabb fokú depressziójával, szorongásával és problémás viselkedésével. Lau (2017) azt találta a vizsgálatában, hogy a triangulációs múködés összefügg a gyermek alacsonyabb önértékelésével is.

A konfliktusok gyakorisága és intenzitása mellett a konfliktusok kezelésének módja szintén meghatározó a közös szülőség szempontjából. A vitarendezés módját is fókuszba helyező tanulmányok (Baum \& Shnit, 2003; Camara \& 
Resnick, 1989; Fishel \& Scanzoni, 1990) szerzői az elvált szülőknél az együttmúködő/kompromisszumkereső, az elkerülő és az ellenséges/versengő/ támadó stratégiákat azonosították. Az öndifferenciálás (az érzések azonosítása és kifejezése, ugyanakkor az impulzus kontrollálása) és a nárcisztikus személyiségjellemzők, valamint a konfliktuskezelési stratégiák kapcsolatát vizsgálta Baum és Shnit (2003). Azt találták, hogy a magasabb öndifferenciáció-pontszámmal rendelkező apák és anyák kevésbé alkalmazták a támadó stratégiát. A magasabb öndifferenciáció a nőknél pozitív korrelációt mutatott a kompromisszumkereső konfliktuskezeléssel, azonban az apáknál nem találtak szignifikáns összefüggést. A konfliktuskezelés tekintetében egyértelmú különbség látszik az egyes közös szülői profillal jellemezhető szülők között. Galovan és Schramm (2017) 1540 szülő megkérdezésével vizsgálták a közös szülőség és a konfliktuskezelés kapcsolatát. Első lépésként a közös szülőség látens profiljait elemezték, majd később az így talált négy profilt, amelyeket Ahrons (1981) nyomán „tüzes ellenségek”, „'haragos munkatársak”, , együttmúködő kollégák” és „,tökéletes barátok” nevekkel írtak le. A konfliktuskezelési pontszám a legmagasabb a tökéletes barátok, a legalacsonyabb pedig a tüzes ellenségek csoportjában volt, ami azt jelzi, hogy a közös szülőség minősége pozitív együttjárást mutat a konstruktív konfliktuskezelési stratégiákkal. A konfliktus csökkentésére irányuló viselkedést Rector LaGraff, Stolz és Brandon (2015) három itemmel mérték, amelyek az együttmúködési technikákra, a hatékony kommunikációra és a gyermek érdekében történő kooperációra vonatkoztak. Longitudinális vizsgálatukban $\left(n_{\mathrm{T} 1-2}=139, n_{\mathrm{T} 3}=106\right)$ azt találták, hogy a közös szülőségre vonatkozó képzési programban részt vevők konfliktuskezelésre és triangulációra vonatkozó ismerete magasabb szintet mutatott, és magatartásuk is konstruktívabb volt a programot követően, mint a képzés kezdetén.

\subsection{Támogatás vs. aláásás}

A támogató közös szülőség (supportive coparenting) fogalmát több tanulmányban (Berryhill, 2017; Kamp Dush, Kotila, \& Schoppe-Sullivan, 2011; Petren és mtsai, 2017) az együttmúködő közös szülőség szinonimájaként használják. A szülők kommunikációja, konfliktuskezelése, a gyermek(ek)kel kapcsolatos feladatok koordinációja mellett a közös szülőség egy fontos és különálló dimenziója a támogatás is: egymás kompetens szülőként való elismerése, egymás döntéseinek tiszteletben tartása és ezzel a szülői tekintély támogatása, egymás szülői erőfeszítéseinek elismerése és értékelése. Ugyanennek a negatív oldala az egymás szülőségének, szülői tekintélyének aláásásában jelenik meg, ami hibáztatásban, sértegetésben és kritizálásban is megmutatkozhat (Feinberg, 2003). Nem teljesen egyértelmú, hogy a tá- 
mogatás és az aláásás ugyanannak a kontinuumnak két pólusaként értelmezhető-e, vagy két egymással negatívan korreláló, de független dimenzióként. A Coparenting Relationship Scale (CRS, Közös Szülőség Kapcsolati Skála) mérőeszközben két alskálaként jelennek meg és a faktorelemzés alapján külön dimenzióként funkcionálnak (Feinberg és mtsai, 2012). Lau és munkatársai (2017) a közös szülői támogatást külön vizsgálták a gyermekkel együtt élő és különélő szülókre vonatkozóan és azt találták, hogy a gyermekkel élő szülők nagyobb fokú támogatásról számoltak be a különélő szülők felé, mint fordítva. A gyermekkel együtt élő szülők támogatása a másik felé mindkét szülőnél szignifikáns összefüggést mutatott a konfliktus mértékével.

Korábbi vizsgálatok eredményei szerint a szülők kölcsönös támogatása, illetve annak hiánya vagy egymás tekintélyének aláásása összefügg a gyermekek externalizáló viselkedési problémáival, hiperaktivitásával és internalizáló zavaraival, míg a magasabb szintú támogatás esetén kevésbé jelentek meg ezek a problémák (Lau, 2017; Pruett, Williams, Insabella, \& Little, 2003). Sőt, úgy túnik, hogy az internalizáló problémákhoz a közös szülőség dimenziói közül az aláásás/támogatás kapcsolódik a legszorosabban (Benson, Buehler, \& Gerard, 2008; Shimkowski \& Schrodt, 2012).

\section{A válás folyamata}

A közös szülőség minőségét befolyásoló tényezők közül kiemelten fontosak a szülők korábbi kapcsolatának, a párkapcsolat felbomlásának és a válási folyamatnak a jellemzői. A válásra hosszú folyamatként tekinthetünk, amely a válás gondolatának felmerülésétől a válás utáni élet megszilárdulásáig tart (Bognár \& Telkes, 1986). A válás folyamata két fó szakaszra tagolódik. Az első az úgynevezett döntéshozó szakasz, amely a válás első gondolatától a tényleges különválásig tart. Ennek a szakasznak az idótartama kb. egy évre tehető. A második fő szakasz az alkalmazkodási szakasz. Ez a tényleges különválástól mint a folyamat meghatározó fordulópontjától számítandó. Ebben az esetben nagyon eltérő, másfél és négy év közé tehető időtartamok figyelhetők meg. E szakasznak a legfontosabb alfolyamata az érzelmi leválás. Ezen kívül párhuzamosan zajlanak még a következő alfolyamatok: jogi válás, a szülő-gyermek kapcsolatok újrarendezése, gazdasági válás, a társas kapcsolatok átrendezése. Ezen alszakaszok eredménye és egyben a második fó szakasz lezárása is, amikor kialakul a stabil identitás és életvitel (Bognár \& Telkes, 1986). Annak ellenére, hogy a szülők múködését jelentősen meghatározhatja, hogy a különválás melyik szakaszában tartanak (különösen annak érzelmi és gazdasági vetületeire tekintettel), az általunk áttekintett tanulmányokban inkább a folyamat jellemzői 
jelentek meg. Ez rámutat egy hiányterületre is: bár a válás szakirodalmának fontos része a válás szakaszainak elemzése, a közös szülőség esetében ez nem kapott ekkora figyelmet.

Baum (2003) négy, a válási folyamattal kapcsolatos kérdés összefüggését vizsgálta a közös szülőséggel: ki kezdeményezte a válást, a felelősségvállalás mértéke a válásért, a válás folyamatának nehézsége, és a válási folyamat hossza. Eredményei azt mutatták, hogy mindegyik tényező összefügg a közös szülőséggel, bár a válás kezdeményezésénél $(r=0,29)$ és a felelősségvállalás mértékénél $(r=0,36)$ gyengébb asszociációt talált, mint a másik két tényezőnél, továbbá ez utóbbiak szorosabb kapcsolatban voltak az apák válást követó érzéseivel és viselkedésével, mint az anyákéival. A folyamat nehézségei (apák: $r=-0,72$; anyák: $r=-0,68$ ) és időtartama (apák: $r=-0,64$; anyák: $r=-0,49)$ mindkét nemnél erős összefüggést mutattak. Egy másik tanulmányában ( $\mathrm{N}=50$ pár) Baum (2004) klaszterelemzés segítségével három csoportot alkotott a közös szülói gyakorlat alapján, majd ezeket jellemezte a válás folyamatára vonatkozó változókkal. Az együttmúködő (cooperative parenting) klasztert jó közös szülői kooperáció, mérsékelt kompromisszumkészség jellemzi, ugyanakkor kevésbé jelenik meg a másik fél támadása. A konfliktusos csoportban (conflictual parenting) a rossz minőségú közös szülőség mellett gyakrabban jelenik meg a támadás, mint konfliktuskezelési stratégia. A párhuzamosnak elnevezett klaszternél (parallel parenting) mindkét félnél a mérsékelt együttmúködés jellemző, azonban a nőknél a másik támadása mérsékelt, a férfiaknál pedig inkább magasnak mondható. A kezdeményezés mértéke az apáknál a konfliktusos csoportban, míg az anyáknál a párhuzamos klaszterben volt alacsonyabb. A felelősségvállalás az apák együttmúködő csoportjában szignifikánsan magasabb volt, az anyáknál viszont nem volt jelentős különbség. A nehézség és időtartam tekintetében az anyáknál és apáknál is az együttmúködő klaszterben lévők jelöltek alacsonyabb értéket. A válási folyamat további fontos eleme lehet, hogy a felek felkeresnek-e mediátort a válásuk során, aki pártatlan harmadik félként segíti a kommunikációs folyamatot a megegyezés elérése érdekében. Sodermans és munkatársai (2013) longitudinális vizsgálatukban $(n=2207)$ azt találták, hogy a megkérdezettek átlagosan 11,5\%-a fordult mediátorhoz, azonban az arány a fiatalabb kohorszoknál magasabb volt. Az elhelyezés típusa és a mediátor felkeresése az első kohorsznál összefüggött - a közös fizikai felügyelet mellett döntők gyakrabban fordultak mediátorhoz. Az idősebb kohorszokban ez a kapcsolat eltúnt, vagyis nőtt a mediáció népszerúsége, ugyanakkor nem kapcsolódott az elhelyezés típusához. Egy másik kutatásban $(n=135)$ (Bonach és mtsai, 2005) a válási folyamat ellenségessége negatív korrelációt mutatott a közös szülőség minőségével $(r=-0,35)$. Nemi különbséget a vizsgált változók közül egyedül a gyermek elhelyezésével kapcsolatos elégedettségre vonatkozóan találtak, a nők nagyobb elégedett- 
ségről számoltak be, mint a férfiak. A közös szülőség minőségét előrejelző változók közül a férfiaknál a válás ellenségessége meghatározó, a nóknél viszont a megbocsátás és a másik fél megbánása után ez csak a harmadik legfontosabb tényezőnek bizonyult (Bonach és mtsai, 2005). A párkapcsolat felbomlásánál gyakran előfordul, hogy a felek nem ugyanott tartanak a folyamatban. Különösen igaz ez az érzelmi válásra. A különválást követően a korábbi negatív kommunikációs mintázatok folytatódhatnak, amíg a pár érzelmi válása ténylegesen meg nem történik. A másik iránti (sokszor még a párkapcsolatból származó, és mint partnerre vonatkozó) érzések nehezítik a szülői szerepekből történő kommunikációt (Altenhofen és mtsai, 2008).

\section{A gyermek elhelyezése}

A közös szülőség - ahogy korábban említettük - arra a módra vonatkozik, ahogy a szülők a gyermekneveléssel, a gyermek életének koordinálásával kapcsolatos kérdéseket kezelik, és ennek érdekében szülői szerepeikben egymással együttmúködnek. Ha ezt tekintjük a közös szülőség tartalmi részének, fontos szót ejteni arról a keretról, amiben mindezt megvalósítják. A válás után kialakuló új családi felállás lehet olyan, hogy döntóen az egyik szülővel él a gyermek, vagy a gondozásáról, neveléséról váltott elhelyezéssel gondoskodnak a szülők. Korábban az volt a jellemző, hogy a gyermek(ek) a válás után elveszíti(k), vagy legalábbis minimálisra csökkenti(k) a kapcsolatot az egyik szülővel, az esetek nagy részében az apával (Amato, 2000). Ez talán több esetben még mindig így van, de egyre gyakoribb, hogy a különélő szülő is aktívan bekapcsolódik a gyermek(ek) életébe (Fransson és mtsai, 2016). Az elmúlt két évtizedben nemzetközi szinten jelentősen növekedett azon családok száma, ahol válást követően váltott elhelyezésben nevelik a gyermeke(ke)t. Erre a formára több kifejezéssel is utalnak a tanulmányokban (shared parenting, joint physical custody, shared custody, dual-residence, shared-time parenting), fó kritériumnak tekinthető azonban, hogy a gyermek az ideje legalább egyharmadát töltse az egyik szülőnél, beleértve hétköznapokat, ünnepeket, és tanítási szüneteket (Andreasson \& Johansson, 2019; Nielsen, 2014). Egy holland tanulmányban (Bakker \& Mulder, 2013) különböző szempontok szerint vizsgálták az egyes elhelyezési formákat (anyai felügyelet vs. megosztott felügyelet) választó családokat. Eredményeik azt jelzik, hogy a földrajzilag egymáshoz közelebb élő, magas iskolai végzettségú szülők gyakrabban választják a váltott elhelyezést. Emellett befolyásoló tényező, hogy milyen volt közöttük a feladatok megosztása a válás előtti idószakban. Az új partnerkapcsolat kialakulása esetén a nőknél inkább jellemző, a férfiaknál kevésbé jellemző a váltott 
elhelyezési forma választása. A gyermekek jellemzőit tekintve egy svéd felmérés (Bergström, Fransson, Hjern, Köhler, \& Wallby, 2014) szerint szignifikánsan több fiú $(57,4 \%)$ nevelkedett váltott elhelyezésben, mint lány. Koreloszlás tekintetében pedig a 12 év alatti gyermekeknél jellemzőbb ez a forma. Megjegyzendő, hogy ez a korcsoporteloszlás egyfajta kohorszhatásnak is tulajdonítható: az elmúlt 12 évben az elvált párok gyakrabban választják a váltott elhelyezést, mint korábban (Bergström és mtsai, 2014).

Több vizsgálatban állították fókuszba a gyermekek jóllétét, illetve pszichés nehézségeit és viselkedési problémáit az elhelyezés függvényében (Bergström és mtsai, 2014; Bergström és mtsai, 2015; Carlsund, Eriksson, \& Sellström, 2012; Fransson, Låftman, Östberg, Hjern, \& Bergström, 2018). A nukleáris családokban élő gyermekek jólléte rendszerint magasabbnak bizonyult az elvált szülők gyermekeinél, ugyanakkor szignifikáns különbség rajzolódott ki a váltott elhelyezésben és az egy szülónél történő elhelyezés között: a legalacsonyabb jóllét az utolsó csoportban mutatkozott. Akadnak azonban olyan vizsgálatok is, ahol a pszichés nehézségek tekintetében nem találtak különbséget a váltott elhelyezésben élő gyermekek és a nukleáris családban élők között (Fransson és mtsai, 2016). Laftman és munkatársai (2014) kimutatták, hogy azok a gyermekek, akiknek a szülei a közös fizikai felügyelet mellett döntöttek, hajlamosabbak voltak mindkét szülöjükhöz fordulni, amikor érzelmi támogatásra volt szükségük.

A recens kutatásokban tehát azt találták, hogy a megosztott felügyeletben élő gyerekek különböző mutatók alapján jobb helyzetben vannak a kizárólagos elhelyezésben élő gyermekeknél, de minden esetben fontos mérlegelni azokat a sajátos körülményeket, adottságokat és lehetőségeket, amelyekkel az adott család rendelkezik. Birnbaum és Saini (2015) olyan kvalitatív vizsgálatok eredményeit gyújtötték össze, ahol váltott elhelyezésben élő gyermekeket kérdeztek meg a szüleik válását követő tapasztalataikról. Pozitívumok között szerepelt a változásra való fogékonyság, azaz a gyermekek növekedésével, illetve a speciális helyzetek kezelésében több tér nyílt az osztott felügyeletet gyakorló családokban. A gyermekek beszámolójából kiemelendő, hogy örültek annak, hogy mindkét szülővel megmaradt az intenzív kapcsolat. A nehézségek között említették a gyakori költözést, ami több esetben egy idő után az elhelyezés formájának megváltoztatásához vezetett. További kihívás volt, hogy azokban az időszakokban, amikor a szülők közötti konfliktus felerősödött, nehezebb volt a mindkét szülővel való együttélés. Fontos eredménynek tartjuk, hogy ha a szülőknek a válás után sikerül jó „munkakapcsolatot” kialakítani, igények szerint megosztani a felelősséget a mindennapi életre vonatkozóan (azaz a közös szülőség kereteit kialakítani), akkor maguk a szülők és a gyermekeik is nagyobb élettel való elégedettséget mutatnak (Lamb \& Kelly, 2009). 


\section{Prevenció és intervenció}

\subsection{Közös szülőség képzési programok}

Az elmúlt évtizedekben több olyan képzési program is indult, amely a válás utáni közös szülőség minőségének fejlesztésére irányult. Az Amerikai Egyesült Államokban az államok többségben (46 államban) már 2007-ben elérhető volt az elvált szülőknek képzés, s az államok több mint a fele (27 állam) megköveteli, hogy a válás előtt álló szülők tanfolyamon vegyenek részt (Pollet \& Lombreglia, 2008). Ezeknek a programoknak az elsődleges célja a szülők együttmúködésének és kommunikációjának fejlesztése annak érdekében, hogy csökkentsék a szülők kapcsolatának felbomlásából adódó negatív hatásokat. A képzések felhívják a szülők figyelmét a konfliktusok gyermek(ek)re gyakorolt kedvezőtlen hatásaira; emellett segítik a szülőket abban, hogy csökkentsék a gyermek(ek) szülői konfliktusoknak való kitettségét, valamint a gyermek(ek) bevonását a vitákba; illetve abban, hogy kialakítsák és fenntartsák a pozitív szülő-gyerek kapcsolatot mindkét szülővel (Galovan \& Schramm, 2017; Goodman, Bonds, Sandler, \& Braver, 2004). A képzések egy része megcélozza azt is, hogy ebben az élethelyzetben megismertesse a szülőkkel a megosztott felügyelettel járó előnyöket, amely leginkább arra vonatkozik, hogy a gyermeknek lehetósége legyen mindkét szülővel folytatni a kapcsolatát és érezni mindkét szülő támogatását (Douglas, 2004).

A Florida állambeli „Successful Co-parenting After Divorce” (Sikeres közös szülőség a válás után) képzési program az erőforrásokra és a pozitív tulajdonságokra összpontosít. Ilyen például a kreativitás, a türelem, a lelkesedés, a kedvesség, amelyek arra ösztönözhetik a szülőket, hogy pozitív attitúddel tudjanak egymás és a gyermek(ek) felé is fordulni, ami jobb, hatékonyabb szülótársi kapcsolathoz vezethet. A program fontos elemeiként kiemelendő a válás traumája és veszteségei, a válás és a közös szülőség során felmerülő legfontosabb kérdések, a közös szülői készségek és stratégiák, és a felek saját pszichológiai jólléte (Ferraro, Malespin, Oehme, Bruker, \& Opel, 2016; Florida State University, 2020).

A „New Beginnings Program” (Új kezdetek program) egy 10 alkalmas csoportmunkára épül, amely a válásban érintett gyermekek jóllétének két empirikusan alátámasztott tényezőjét, nevezetesen a közös szülőség minőségét és a gyermek(ek) konfliktusnak való kitettségét helyezi a fókuszba. A programnak a két szülő és a gyermekek beszámolója alapján egyaránt szignifikáns, kedvező hatása volt a közös szülőség több aspektusára, amit azonban jelentősen moderált az etnikai hovatartozás és a gyermek életkora, az idősebb gyermekeknél erősebb hatást találtak (Sandler és mtsai, 2018; Sandler és mtsai, 2020). 
A „Dad for Life" (Apa egy életre) egy csoportos prevenciós program különélő apák számára, amelynek célja a válás kockázatainak csökkentése és a gyermekek jóllétének növelése. A programnak két fókusza van: egyfelől az apa-gyerek kapcsolat építése az apa szülói készségeinek fejlesztésével; másfelól az apa-anya kapcsolat befolyásolása, a konfliktusok csökkentése - különösen azoké, amelyek a gyerekek előtt zajlanak -, valamint a jobb közös szülői kapcsolat támogatása. A program nyolc csoportos és két egyéni ülést tartalmaz, amelynek egyik felében a szülői készségekkel (értó figyelem, kommunikáció, hatékony fegyelmezés), a másik felében pedig a szülők közötti konfliktusokkal foglalkoznak. A programot értékelve 214 apa és anya megkérdezésével azt találták, hogy az anyák felfogása, miszerint egy barátságos szülói kapcsolatot szeretnének kiépíteni az apával, két évvel a válás után alábbhagy és az apák részvétele csökken. A felmérés statisztikailag igazolta, hogy a program ezt a tendenciát meg tudja fordítani, és az apai részvétel idővel növekszik (Sandler, Miles, Cookston, \& Braver, 2008).

Galovan és Schramm (2017) arra is felhívják a figyelmet, hogy a programok adott célközönséghez igazítása nagymértékben növeli azok hatékonyságát. A „Focus on Kids” (Gyerekek a fókuszban) program 1883 résztvevőjével végzett felmérésükben különböző közös szülőség típusokat (lásd Ahrons [1981] korábban említett tipológiáját) vizsgálva jutottak arra a következtetésre, hogy a közös szülőségi sajátosságok, mintázatok és a képzés módszerének, curriculumának jó illeszkedéséhez elengedhetetlen a képzések testreszabása. A közös szülőség képzések univerzális, néhány órás programjai hasznosak lehetnek egyeseknek, azonban többen igényelnek intenzívebb és valamilyen témára fókuszáló programokat (Salem, Sandler, \& Wolchik, 2013).

\subsection{Válási mediáció}

A mediáció - más néven közvetítés - egy széleskörúen elterjedt alternatív vitarendezési eljárás. A mediációban egy pártatlan és semleges harmadik fél segíti a felek kommunikációját és a tárgyalási folyamatot, amelynek célja egy mindkét fél számára elfogadható megállapodás elérése. A peres eljárásban megjelenő „nyertes-vesztes” pozicionális tárgyalás helyett a mediáció a vitarendezés együttmúködésen alapuló modelljét kínálja és a „nyertesnyertes" megállapodást célozza. Egy 12 évet felölelő longitudinális vizsgálat ( $\mathrm{N}=71$ család) eredményei szerint a mediáció elősegítette a szülők közötti hatékonyabb kommunikációt, javította a különélő szülő és a gyermek kapcsolatát és hozzájárult a különélő szülő magasabb szintû részvételéhez a gyermek életében (Emery és mtsai, 2001). Ugyanezen adatbázist elemezve Sbarra és Emery (2008) azt találták, hogy a mediáción részt vevőknél már 
rövid távon csökkent a másik szülővel való konfliktus, míg a perbeli tárgyalást választóknál gyakoribbak lettek a konfliktusok.

\subsection{Válási terápia}

Válás közben és után a pároknak többféle terápiás célú lehetőségük is nyílik segítséget kérni a kapcsolatuk rendezésére. Különböző válási szakaszban, különböző helyzetben lévő pároknál eltérő lehet, hogy melyik beavatkozási forma hatékony. Vannak, akiknél a szülőtársi kapcsolatot szükséges erősíteni, és van, ahol a szülő-gyermek kapcsolatot célszerú támogatni. Előfordulhat olyan helyzet, amikor hasznos, ha az egész család részt vesz a terápiás ülésen, és akad olyan is, amikor a felek egyéni terápiája a megfeleló (Togliatti, Lavadera, \& Benedetto, 2011). Wall és munkatársai (1999) kutatásából kiderül, hogy a házassági terapeuták $60 \%$-a semlegesen áll a válás és a házasság kérdéséhez. Vagyis az ügyfeleik jóllétét tartják szem előtt, függetlenül attól, hogy tudnak-e lépéseket tenni a házasságuk javítása érdekében, vagy válással végződik a kapcsolat. Amikor a pár elhatározta magát a válást illetőleg, akkor a családterapeuták abban tudnak segíteni, hogy "jó válás" jöhessen létre, vagyis a lehető legkevesebb sérülést kelljen átélni mindkét félnek, illetve a gyermek(ek)nek (Doherty, 2002). Lebow (2015) egy speciális válásterápiát fejlesztett ki, integratív szemlélettel. A válás kezdeti fázisára fókuszál, amikor még a pár érzelmei igen intenzívek. A terápia célja a gyermek kapcsán kialakuló problémák, illetve konfliktusok oldása, az érzelmi leválás és az indulatkezelés segítése. Gürmen és munkatársai (2017) érvelése szerint a családterapeuták a válás után abban lehetnek a pár segítségére, hogy alternatív módszereket találhassanak a konfliktusok enyhítésére a közös szülőség kapcsán. Rávilágíthatnak arra, hogy nem csupán szülőtársként kapcsolódnak, de volt házastársi szerepük is összeköti őket. Biztonságos térben mondhatják el egymás iránti gondolataikat és érzelmeiket, amely hozzájárul a jóllétükhöz.

E néhány megközelítésből is látszik, hogy nem mindig egyértelmú a határvonal a válási terápia és a válási mediáció között, noha a tisztább kompetenciahatárokkal való múködés is hozzájárulna a válási folyamat hatékonyabb támogatásához és a közös szülőség sikeréhez. Véleményünk szerint - amit alátámaszt az Amerikai Pszichológiai Társaság iránymutatása is (American Psychological Association, 2013) - a terápiás támogatás elsősorban a párkapcsolat felbomlását kíséró érzelmek kezelését és a változásokhoz való alkalmazkodást segítheti. Az egyéni és párterápiák a válás előtt és közben hozzájárulnak a felek önismereti fejlődéséhez, annak átgondolásához, hogy mi volt diszfunkcionális a felbomlott párkapcsolatban, és milyen ismétlődő mintákat lenne érdemes elkerülni egy következő párkapcsolat- 
ban. Természetesen a válási mediáció során is elókerülnek a felek érzelmei, azonban a fókuszban azon kérdések tisztázása áll, amelyek segítik a szülőtársként való múködést a jövőben, elsősorban a felek és a gyermek(ek) szükségletei, illetve érdekei figyelembevételével.

\subsection{Szülői koordináció}

A szülői koordináció (parenting coordination) egy olyan támogató forma, amely kimondottan a konfliktusos válások segítését szolgálja egyes országokban. Célja a szülők közötti kommunikáció fejlesztése, akár képzéssel, akár kommunikációs készségekre fókuszáló coachinggal (Demby, 2016). A program lényege, hogy a szülők komplex, sokoldalú segítséget kapnak, amely ötvözi a bírósági, a tanácsadói, és a családi mediátori szerepeket és tevékenységeket (Johnston \& Janet, 2000), úgy, hogy a legtöbb téma a gyermekkel kapcsolatos kommunikációra fókuszál (Mitcham-Smith \& Henry, 2007). A szülői koordináció fő feladatai közé tartozik a megosztott szülői felügyeleti terv létrehozása, illetve módosítása a konfliktusok minimalizálása mellett; a terv hatékony végrehajtásának figyelemmel kísérése, segítése; konfliktuskezelés és hatékony kommunikációs készségek oktatása; valamint a szülők segítése abban, hogy a gyermeke(ke)t ösztönözni tudják a másik féllel való aktív kapcsolattartásra. A fentieken túl pszichológiai ellátást is biztosítanak a szülóknek, amennyiben igényt tartanak rá (Coates, Deutsch, Starnes, Sullivan, \& Sydlik, 2004). A modellt az 1990-es évek elején Colorado és Kalifornia államokban fejlesztették ki, és mára több mint 30 államban múködik (Demby, 2016). A program hatékonyságának empirikus vizsgálata szórványosan és alacsony elemszám mellett történt csak meg, azonban az eredmények arra utalnak, hogy a kimondottan konfliktusos esetekben jelentősen csökkent az elindított bírósági ügyek száma (O’Hara, Beck, Anderson, \& Benjamin, 2011).

\section{Következtetések és javaslatok}

A párkapcsolat felbomlását követő szülői együttmúködés és az elvált szülők konfliktusainak témájáról hazai empirikus adatok nem, illetve csak rendkívül korlátozottan állnak rendelkezésünkre (Szalma \& Rékai, 2019). E kérdéskör a szakmai kommunikációban is csak szórványosan jelenik meg, és a hangsúly szinte kizárólag a konfliktusos válások dilemmáira kerül. A közös szülőség szakirodalmának áttekintése alapján fontosnak tartjuk a kérdéssel foglalkozó segítő szakemberek, kutatók és szakpolitikusok figyelmét felhívni néhány szempontra. 
A válás utáni közös szülőség, különösen a szülők közötti konfliktusok megértése, mérése és kezelése gyakran kihívást jelent, mivel a két fél mást észlel, mást tart fontosnak, ráadásul máshogy is interpretál. Az egyik fél nagyobb ellenségességet mutathat, mint a másik; másfajta konfliktuskezelési stratégiákat használhatnak (pl. az egyik elkerül, a másik perel); és máshol is tarthatnak a válási folyamatban, az érzelmi leválásban. Különböző diádikus nézőpontok és interakciók teszik komplexszé és dinamikussá a kapcsolati teret. Ebből fakadóan olyan kutatási megközelítést szükséges alkalmazni, amely minél jobban meg tudja ragadni ezt a komplexitást. Ha egy párkapcsolati múködésnél indokolt a diádikus megközelítés a kutatás tervezésénél, akkor az elvált (és a válófélben lévő) szülook kapcsolatának vizsgálata során ez hatványozottan igaz. A diádkutatások során tehát a fókusz a két személy közötti kapcsolat megértésén van, amit a megfelelő kép érdekében több perspektívából is szükséges megvilágítunk.

A demográfiai trendek megismeréséhez szükségesek a nagymintás panelvizsgálatok, ugyanakkor a válás utáni közös szülóség dinamikájának és mintázatainak jobb megismeréséhez elengedhetetlen a fókuszált „mélyfúrás” - akár a témára vonatkozó részletes kérdőívvel, akár kvalitatív módszertannal. A Függelékben feltüntettük a kérdés vizsgálata során leggyakrabban használt mérőeszközöket, ami segítséget jelenthet a közös szülőségre irányuló jövőbeli kutatások tervezésében.

A nemzetközi empirikus tapasztalatok alapján evidenciaként tekinthetünk a közös szülői kapcsolat minőségének és a gyermekek jóllétének összefüggésére. Erre alapozva számos országban önkéntes vagy kötelező, bíróság által elrendelt módon prevenciós képzési programokat indítottak a válási átmenet támogatása és a közös szülői gyakorlat fejlesztése érdekében. Hazánkban léteznek szülői (parenting) tréningek, információs portálok, amelyek különböző szülői készségek fejlesztését tűzik ki célul. Erre példák a Családbarát Ország projektjében indított szülőcsoportok (CSBO, 2020), vagy a Hintalovon Gyermekjogi Alapítvány Yelon kampányának szülőknek szóló oldala (Yelon, 2021). Teljes mértékben hiányoznak azonban a közös szülőségre (coparenting) fókuszáló képzési programok. A kérdés társadalmi fontosságát tekintve kiemelt feladatnak tartjuk a prevenciós program(ok) kidolgozását, hatékonyságuk felmérését és a hatékonynak bizonyuló programok rendszerszintú bevezetését, segítve ezzel az elvált szülők és gyermekeik alkalmazkodását a válás okozta új helyzethez. 


\section{Irodalom}

Abidin, R. R., \& Brunner, J. F. (1995). Development of a parenting alliance inventory. Journal of Clinical Child Psychology, 24(1), 31-40.

Achenbach, T. M. (1991). Manual for the child behavior checklist and 1991 profile. Vermont: University of Vermont, Department of Psychiatry

Adamsons, K., \& Johnson, S. K. (2013). An updated and expanded meta-analysis of nonresident fathering and child well-being. Journal of Family Psychology, 27(4), 589-599.

Ahrons, C. R. (1981). The continuing coparental relationship between divorced spouses. American Journal of Orthopsychiatry, 51(3), 415-428.

Ahrons, C. R., \& Miller, R. B. (1993). The effect of the post-divorce relationship on paternal involvement: A longitudinal analysis. American Journal of Orthopsychiatry, 63(3), 441-450.

Altenhofen, S., Biringen, Z., \& Mergler, R. (2008). Significant family dynamics related to postdivorce adjustment in parents and children. Journal of Divorce and Remarriage, 49(1-2), 25-40.

Amato, P. R. (2000). The consequences of divorce for adults and children. Journal of Marriage and Family, 62(4), 1269-1287.

Amato, P. R. (2010). Research on divorce: Continuing trends and new developments. Journal of Marriage and Family, 72(3), 650-666.

Amato, P. R., \& Gilbreth, J. G. (1999). Nonresident fathers and children's well-being: A metaanalysis. Journal of Marriage and Family, 61(3), 557-573.

Amato, P. R., Kane, J. B., \& James, S. (2011). Reconsidering the "good divorce". Family Relations, 60(5), 511-524.

American Psychological Association (2013). Healthy divorce: How to make your split as smooth as possible. Letöltve: 2021. 03. 04. https:// www.apa.org/topics/divorce-child-custody/ healthy

Anderson, S., Anderson, S., Palmer, K., Mutchler, M., \& Baker, L. (2011). Defining high conflict. The American Journal of Family Therapy, 39, 11-27.

Andreasson, J., \& Johansson, T. (2019). Becoming a half-time parent: Fatherhood after divorce. Journal of Family Studies, 25(1), 2-17.

Bakker, W., \& Mulder, C. H. (2013). Characteristics of post-separation families in the Netherlands: Shared residence versus resident mother arrangements. GeoJournal, 78(5), 851-866.

Barth, K. (2013). Theoretical Approach to understanding the factors influencing divorcing parents' readiness to co-parent. Oklahoma State University: Stillwater. Letöltve: 2021. március 20-án: https://shareok.org/bitstream/handle/11244/49039/Barth_okstate_0664M_ 14742.pdf?sequence=1\&isAllowed $=\mathrm{y}$

Bastaits, K., \& Mortelmans, D. (2016). Parenting as mediator between post-divorce family structure and children's well-being. Journal of Child and Family Studies, 25(7), 2178-2188.

Bastaits, K., Ponnet, K., \& Mortelmans, D. (2012). Parenting of divorced fathers and the association with children's self-esteem. Journal of Youth and Adolescence, 41(12), 1643-1656.

Bastaits, K., Ponnet, K., \& Mortelmans, D. (2014). Do divorced fathers matter? The impact of parenting styles of divorced fathers on the well-being of the child. Journal of Divorce and Remarriage, 55(5), 363-390.

Baum, N. (2003). Divorce process variables and the co-parental relationship and parental role fulfillment of divorced parents. Family Process, 42(1), 117-131.

Baum, N. (2004). Typology of post-divorce parental relationships and behaviors. Journal of Divorce and Remarriage, 41(3-4), 53-79. 
Baum, N., \& Shnit, D. (2003). Divorced parents' conflict management styles. Journal of Divorce and Remarriage, 39(3-4), 37-58.

Becher, E. H., Kim, H., Cronin, S. E., Deenanath, V., McGuire, J. K., McCann, E. M., et al. (2019). Positive parenting and parental conflict: Contributions to resilient coparenting during divorce. Family Relations, 68(1), 150-164.

Beckmeyer, J. J., Coleman, M., \& Ganong, L. H. (2014). Postdivorce coparenting typologies and children's adjustment. Family Relations, 63(4), 526-537.

Beckmeyer, J. J., Ganong, L. H., Coleman, M., \& Markham, M. S. (2017). Experiences with coparenting scale: A semantic differential measure of postdivorce coparenting satisfaction. Journal of Family Issues, 38(10), 1471-1490.

Beckmeyer, J. J., Markham, M. S., \& Troilo, J. (2019). Postdivorce coparenting relationships and parent-youth relationships: Are repartnership and parent-youth contact moderators? Journal of Family Issues, 40(5), 613-636.

Benson, M. J., Buehler, C., \& Gerard, J. M. (2008). Interparental hostility and early adolescent problem behavior: Spillover via maternal acceptance, harshness, inconsistency, and intrusiveness. The Journal of Early Adolescence, 28(3), 428-454.

Bergman, A.-S., \& Rejmer, A. (2017). Parents in child custody disputes: Why are they disputing? Journal of Child Custody, 14(2-3), 134-150.

Bergström, M., Fransson, E., Hjern, A., Köhler, L., \& Wallby, T. (2014). Mental health in Swedish children living in joint physical custody and their parents' life satisfaction: A cross-sectional study. Scandinavian Journal of Psychology, 55(5), 433-439.

Bergström, M., Fransson, E., Modin, B., Berlin, M., Gustafsson, P. A., \& Hjern, A. (2015). Fifty moves a year: Is there an association between joint physical custody and psychosomatic problems in children? Journal of Epidemiology and Community Health, 69(8), 769-774.

Bergström, M., Sarkadi, A., Hjern, A., \& Fransson, E. (2019). “We also communicate through a book in the diaper bag" - Separated parents' ways to coparent and promote adaptation of their 1-4 year olds in equal joint physical custody. PLOS ONE, 14(4), e0214913. DOI: 10.1371/journal.pone.0214913

Berryhill, M. B. (2017). Coparenting and parental school involvement. Child and Youth Care Forum, 46(2), 261-283.

Birkás, E., Lakatos, K., Tóth, I., \& Gervai, J. (2008). Gyermekkori viselkedési problémák felismerésének lehetőségei rövid kérdőívekkel I: a Strengths and Difficulties Questionnaire magyar változata. Psychiatria Hungarica, 23(5), 358-365.

Birnbaum, R., \& Saini, M. (2015). A qualitative synthesis of children's experiences of shared care post divorce. International Journal of Children's Rights, 23(1), 109-132.

Bognár, G., \& Telkes, J. (1986). A válás lélektana. Budapest: Közgazdasági és Jogi Könyvkiadó

Bonach, K. (2005). Factors contributing to quality coparenting. Journal of Divorce and Remarriage, 43(3-4), 79-103.

Bonach, K., \& Sales, E. (2002). Forgiveness as a mediator between post divorce cognitive processes and coparenting quality. Journal of Divorce and Remarriage, 38(1-2), 17-38.

Bonach, K., Sales, E., \& Koeske, G. (2005). Gender differences in perceptions of coparenting quality among expartners. Journal of Divorce and Remarriage, 43(1-2), 1-28.

Buchanan, C. M., Maccoby, E. E., \& Dornbusch, S. M. (1991). Caught between parents: Adolescents' experience in divorced homes. Child Development, 62(5), 1008-1029.

Camara, K. A., \& Resnick, G. (1989). Styles of conflict resolution and cooperation between divorced parents: Effects on child behavior and adjustment. The American Journal of Orthopsychiatry, 59(4), 560-575.

Cantril, H. (1965). The pattern of human concerns. New Brunswick: Rutgers University Press 
Carlsund, Å., Eriksson, U., \& Sellström, E. (2012). Shared physical custody after family split-up: Implications for health and well-being in Swedish schoolchildren. Acta Paediatrica, 102(3), 318-323.

Coates, C., Deutsch, R., Starnes, H., Sullivan, M., \& Sydlik, B. (2004). Parenting coordination for high-conflict families. Family Court Review, 42, 246-262.

Cohen, O., \& Levite, Z. (2012). High-conflict divorced couples: Combining systemic and psychodynamic perspectives. Journal of Family Therapy, 34(4), 387-402.

Cohen, S., Kamarck, T., \& Mermelstein, R. (1983). A global measure of perceived stress. Journal of Health and Social Behavior, 24(4), 385-396.

Cookston, J. T., Braver, S. L., Griffin, W. A., De Lusé, S. R., \& Miles, J. C. (2007). Effects of the dads for life intervention on interparental conflict and coparenting in the two years after divorce. Fam Process, 46(1), 123-137.

CSBO (2020). Szülőcsoportok indulnak. Letöltve: 2021. március 21-én: https:/ / www.csbo. $\mathrm{hu} /$ hirek/63

Demby, S. L. (2016). Parenting coordination: Applying clinical thinking to the management and resolution of post-divorce conflict. 72(5), 458-468.

Diener, E., Emmons, R. A., Larsen, R. J., \& Griffin, S. (1985). The satisfaction with life scale. Journal of Personality Assessment, 49(1), 71-75.

Doherty, W. J. (2002). How therapists harm marriages and what we can do about it. Journal of Couple and Relationship Therapy, 1(2), 1-17.

Douglas, E. (2004). The effectiveness of a divorce education program on father involvement. Journal of Divorce and Remarriage, 40, 91-101.

Drapeau, S., Gagné, M.-H., Saint-Jacques, M.-C., Lépine, R., \& Ivers, H. (2009). Post-separation conflict trajectories: A longitudinal study. Marriage and Family Review, 45(4), 353-373.

Dunn, J., O'Connor, T. G., \& Cheng, H. (2005). Children's responses to conflict between their different parents: Mothers, stepfathers, nonresident fathers, and nonresident stepmothers. Journal of Clinical Child and Adolescent Psychology, 34(2), 223-234.

Dworkin, J. (2016). Coparenting in the digital era: Exploring divorced parents' use of technology. In E. McCann (Ed.), Divorce, separation, and remarriage: The transformation of family (Vol. 10, 279-298). Emerald Group Publishing Limited

Elam, K. K., Sandler, I., Wolchik, S., \& Tein, J.-Y. (2016). Non-residential father-child involvement, interparental conflict and mental health of children following divorce: A person-focused approach. Journal of Youth and Adolescence, 45(3), 581-593.

Elam, K. K., Sandler, I., Wolchik, S. A., Tein, J.-Y., \& Rogers, A. (2019). Latent profiles of postdivorce parenting time, conflict, and quality: Children's adjustment associations. Journal of Family Psychology, 33(5), 499-510.

Emery, R. E., Laumann-Billings, L., Waldron, M. C., Sbarra, D. A., \& Dillon, P. (2001). Child custody mediation and litigation: Custody, contact, and coparenting 12 years after initial dispute resolution. Journal of Consulting and Clinical Psychology, 69(2), 323-332.

Fabricius, W. V., \& Luecken, L. J. (2007). Postdivorce living arrangements, parent conflict, and long-term physical health correlates for children of divorce. Journal of Family Psychology (Division 43), 21(2), 195-205.

Fabricius, W. V., Sokol, K. R., Diaz, P., \& Braver, S. (2012). Parenting time, parent conflict, parent-child relationships, and children's physical health. In K. Kuehnle \& L. Drozd (Eds.), Parenting plan evaluations: Applied research for the family court (188-213). Oxford: Oxford University Press

Feinberg, M. E. (2003). The internal structure and ecological context of coparenting: A framework for research and intervention. Parenting Science and Practice, 3(2), 95-131.

Feinberg, M. E., Brown, L. D., Kan, M. L. (2012). A multi-domain self-report measure of coparenting. Pareningt Science and Practice, 12(1), 1-21. 
Ferraro, A. (2017). Co-parenting in the context of divorce: Evaluation and application of the Multidimensional Co-Parenting Scales for dissolved relationships [Dissertation, Florida State University]. ddu. Tallahassee. Letöltve: 2021. 03. 22-én: https://diginole.lib.fsu.edu/ islandora/object/fsu:552063/datastream/PDF/view

Ferraro, A., Malespin, T., Oehme, K., Bruker, M., \& Opel, A. (2016). Advancing co-parenting education: Toward a foundation for supporting positive post-divorce adjustment. Child and Adolescent Social Work Journal, 33(5), 407-415.

Ferraro, A. J., Lucier-Greer, M., \& Oehme, K. (2018). Psychometric evaluation of the Multidimensional Co-Parenting Scale for dissolved relationships. Journal of Child and Family Studies, 27(9), 2780-2796.

Finzi-Dottan, R., \& Cohen, O. (2014). Predictors of parental communication and cooperation among divorcing spouses. Journal of Child and Family Studies, 23(1), 39-51.

Fishel, A. H., \& Scanzoni, J. (1990). An exploratory study of the post-divorce coparental relationship. Journal of Divorce, 13(2), 95-119.

Florida State University (2020). Succesful co-parenting after divorce. https:/ / coparenting.fsu. edu/

Fransson, E., Låftman, S. B., Östberg, V., Hjern, A., \& Bergström, M. (2018). The living conditions of children with shared residence - the Swedish example. Child Indicators Research, 11(3), 861-883.

Fransson, E., Turunen, J., Hjern, A., Östberg, V., \& Bergström, M. (2016). Psychological complaints among children in joint physical custody and other family types: Considering parental factors. Scandinavian Journal of Public Health, 44(2), 177-183.

Galovan, A. M., \& Schramm, D. G. (2017). Initial coparenting patterns and postdivorce parent education programming: A latent class analysis. Journal of Divorce and Remarriage, 58(3), 212-226.

Ganong, L. H., Coleman, M., Feistman, R., Jamison, T., \& Stafford Markham, M. (2012). Communication technology and postdivorce coparenting. Family Relations, 61(3), 397-409.

Garber, B. D. (2014). The chameleon child: Children as actors in the high conflict divorce drama. Journal of Child Custody, 11(1), 25-40.

Gigy, L., \& Kelly, J. B. (1992). Reasons for divorce: Perspectives of divorcing men and women. Journal of Divorce and Remarriage, 18(1-2), 169-187.

Glasl, F. (1999). Confronting conflict: a first aid kit for handling conflict. Lansdown: Hawthorn Press

Goodman, M., Bonds, D., Sandler, I., \& Braver, S. (2004). Parent psychoeducational programs and reducing the negative effects of interparental conflict following divorce. Family Court Review, 42, 263-279.

Goodman, R. (1997). The Strengths and Difficulties Questionnaire: A research note. Journal of Child Psychology and Psychiatry, 38(5), 581-586.

Grych, J. H., Seid, M., \& Fincham, F. D. (1992). Assessing marital conflict from the child's perspective: the Children's Perception of Interparental Conflict Scale. Child Development, 63(3), 558-572.

Gürmen, M. S., Huff, S. C., Brown, E., Orbuch, T. L., \& Birditt, K. S. (2017). Divorced yet still together: ongoing personal relationship and coparenting among divorced parents. Journal of Divorce and Remarriage, 58(8), 645-660.

Haddad, L., Phillips, K., \& Bone, J. M. (2016). High-conflict divorce: A review of the literature. American Journal of Family Law, 29(4), 243-258.

Hald, G. M., Strizzi, J. M., Ciprić, A., \& Sander, S. (2020). The Divorce Conflict Scale. Journal of Divorce and Remarriage, 61(2), 83-104. 
Hardesty, J. L., Crossman, K. A., Khaw, L., \& Raffaelli, M. (2016). Marital violence and coparenting quality after separation. Journal of Family Psychology, 30(3), 320-330.

Jamison, T. B., Coleman, M., Ganong, L. H., \& Feistman, R. E. (2014). Transitioning to postdivorce family life: A grounded theory investigation of resilience in coparenting. Family Relations, 63(3), 411-423.

Johnston, J.-R. (2000). Building multidisciplinary professional partnerships with the court of behalf of high-conflict divorcing families and their children: Who needs what kind of help. University of Arkansas at Little Rock Law Review, 22(3), 7. Letöltve: 2021. március 25-én: https:/ / lawrepository.ualr.edu/lawreview/vol22/iss3/7

Kamp Dush, C. M., Kotila, L. E., \& Schoppe-Sullivan, S. J. (2011). Predictors of supportive coparenting after relationship dissolution among at-risk parents. Journal of Family Psychology (Division 43), 25(3), 356-365.

Keating, A., Sharry, J., Murphy, M., Rooney, B., \& Carr, A. (2016). An evaluation of the Parents Plus - Parenting When Separated programme. Clinical Child Psychol Psychiatry, 21(2), 240-254.

Kelly, J. B. (2012). Risk and protective factors associated with child and adolescent adjustment following separation and divorce: Social science applications. In K. Kuehnle, \& L. Drozd (Eds.), Parenting plan evaluations: Applied research for the family court (49-84). Oxford: Oxford University Press

Kerig, P. (1996). Assessing the links between interparental conflict and child adjustment: the conflicts and problem-solving scales. Journal of Family Psychology, 10(4), 454-473.

Kovacs, M. (1981). Rating scales to assess depression in school-aged children. Acta Paedopsychiatr, 46(5-6), 305-315.

KSH (2019). Statisztikai tükör - A válások demográfiai jellemzői. Budapest: KSH

Låftman, S., Bergström, M., Modin, B., \& Ostberg, V. (2014). Joint physical custody, turning to parents for emotional support, and subjective health: A study of adolescents in Stockholm, Sweden. Scandinavian Journal of Public Health, 42(5), 456-462.

Lamb, M., \& Kelly, J. (2009). Improving the quality of parent-child contact in separating families with infants and young children: empirical research foundations. In R. M. Galazter-Levy, J. Kraus, \& J. Galatzer-Levy (Eds.), The scientific basis of child custody decisions (2nd ed., (187-214). Hoboken: Wiley

Lamela, D., \& Figueiredo, B. (2011). Post-divorce representations of marital negotiation during marriage predict parenting alliance in newly divorced parents. Sexual Relationship Therapy, 26(2), 182-190.

Lamela, D., \& Figueiredo, B. (2016). Coparenting after marital dissolution and children's mental health: A systematic review. Jornal de Pediatria, 92(4), 331-342.

Lamela, D., Figueiredo, B., Bastos, A., \& Feinberg, M. (2016). Typologies of post-divorce coparenting and parental well-being, parenting quality and children's psychological adjustment. Child Psychiatry and Human Development, 47(5), 716-728.

Langlais, M. R., Anderson, E. R., \& Greene, S. M. (2016). Consequences of dating for postdivorce maternal well-being. Journal of Marriage and Family, 78(4), 1032-1046.

Lansford, J. E. (2009). Parental divorce and children's adjustment. Perspectives on Psychological Science, 4(2), 140-152.

Lau, Y.-K. (2017). Postdivorce coparenting and children's well-being in Hong Kong. Journal of Divorce and Remarriage, 58(5), 329-346.

Lebow, J. L. (2015). Separation and divorce issues in couple therapy. In A. S. Gurman, J. L. Lebow, \& D. K. Snyder (Eds.), Clinical handbook of couple therapy (5th ed., 445-463). New York: The Guilford Press 
Lucas, N., Nicholson, J. M., \& Erbas, B. (2013). Child mental health after parental separation: The impact of resident/non-resident parenting, parent mental health, conflict and socioeconomics. Journal of Family Studies, 19(1), 53-69.

Maccoby, E. E., Depner, C. E., \& Mnookin, R. H. (1990). Coparenting in the second year after divorce. Journal of Marriage and Family, 52(1), 141-155.

Madden-Derdich, D. A., \& Leonard, S. A. (2002). Shared experiences, unique realities: formerly married mothers' and fathers' perceptions of parenting and custody after divorce. 51(1), 37-45.

Madden-Derdich, D. A., Leonard, S. A., \& Christopher, F. S. (1999). Boundary ambiguity and coparental conflict after divorce: an empirical test of a family systems model of the divorce process. Journal of Marriage and Family, 61(3), 588-598.

Margolin, G., Gordis, E. B., \& John, R. S. (2001). Coparenting: A link between marital conflict and parenting in two-parent families. Journal of Family Psychology, 15(1), 3-21.

Markham, M. S., \& Coleman, M. (2012). The Good, the Bad, and the Ugly: Divorced mothers' experiences with coparenting. Family Relations, 61(4), 586-600.

Martos, T., Sallay, V., Désfalvi, J., Szabó, T., \& Ittzés, A. (2014). Az Élettel való Elégedettség Skála magyar változatának (SWLS-H) pszichometriai jellemzői. Mentálhigiéné és Pszichoszomatika, 15(3), 289-303.

Mayes, L. C., \& Moliter-Siegl, A. (1999). The impact of divorce on infants and very young children. In R. M. Galatzer-Levy \& L. Kraus (Eds.), The scientific basis of child custody decisions (188-204). New York: Wiley

McDaniel, B. T., Galovan, A. M., Cravens, J. D., \& Drouin, M. (2018). “Technoference” and implications for mothers' and fathers' couple and coparenting relationship quality. Computers in Human Behavior, 80, 303-313.

McDaniel, B. T., Teti, D. M., \& Feinberg, M. E. (2017). Assessing coparenting relationships in daily life: The daily coparenting scale (D-Cop). Journal of Child and Family Studies, 26(9), 2396-2411.

McHale, J. P., Kuersten-Hogan, R., \& Rao, N. (2004). Growing points for coparenting theory and research. Journal of Adult Development, 11(3), 221-234.

Mitcham-Smith, M., \& Henry, W. J. (2007). High-conflict divorce solutions: Parenting coordination as an innovative co-parenting intervention. The Family Journal, 15(4), 368373.

Modecki, K. L., Hagan, M. J., Sandler, I., \& Wolchik, S. A. (2015). Latent profiles of nonresidential father engagement six years after divorce predict long-term offspring outcomes. Journal of Clinical Child and Adolescent Psychology, 44(1), 123-136.

Moore, C. W. (2014). The mediation process: practical strategies for resolving conflict. Hoboken: Jossey-Bass Publishers

Mullett, E. K., \& Stolberg, A. (1999). The development of the co-parenting behaviors questionnaire. Journal of Divorce and Remarriage, 31(3-4), 115-137.

Nielsen, L. (2014). Shared physical custody: summary of 40 studies on outcomes for children. Journal of Divorce and Remarriage, 55(8), 613-635.

O'Hara, K., Beck, C., Anderson, E., \& Benjamin, G. (2011). Evaluating parenting coordination programs: encouraging results from pilot testing a research methodology. Journal of Child Custody, 8(4), 247-267.

Oppenheim, D., \& Koren-Karie, N. (2012). Parents' insightfulness: The importance of keeping the inner world of the child in mind for parenting plan evaluations. In K. F. Kuehnle \& L. M. Drozd (Eds.), Parenting plan evaluations: Applied research for the family court. Oxford: Oxford University Press

Owen, J., \& Rhoades, G. K. (2012). Reducing interparental conflict among parents in contentious child custody disputes: An initial investigation of the Working Together Program. Journal of Marital and Family Therapy, 38(3), 542-555. 
Petren, R. E., Ferraro, A. J., Davis, T. R., \& Pasley, K. (2017). Factors linked with coparenting support and conflict after divorce. Journal of Divorce and Remarriage, 58(3), 145-160.

Pollet, S. L., \& Lombreglia, M. (2008). A nationwide survey of mandatory parent education. Family Court Review, 46(2), 375-394.

Porter, B., \& O'Leary, K. D. (1980). Marital discord and childhood behavior problems. Journal of Abnormal Child Psychology, 8(3), 287-295.

Pruett, M., Williams, T., Insabella, G., \& Little, T. (2003). Family and legal indicator of child adjustment to divorce among families with young children. Journal of Family Psychology (Division 43), 17, 169-180.

Qu, L., Weston, R., Moloney, L., Kaspiew, R., \& Dunstan, J. (2014). Post-separation parenting, property and relationship dynamics after five years. Melbourne: Australian Institute of Family Studies

Rector LaGraff, M., Stolz, H. E., \& Brandon, D. J. (2015). Longitudinal program evaluation of "Parenting apart: effective co-parenting". Journal of Divorce and Remarriage, 56(2), 117-136.

Rosenberg, M. (1965). Society and the adolescent self-image. Princeton: Princeton University Press

Rózsa, S., Gádoros, J., \& Kő, N. (1999). A gyermekviselkedési kérdőív diagnosztikai megbízhatósága és a több információforráson alapuló jellemzések sajátosságai. Psychiatria Hungarica, 14(4), 375-392.

Rózsa, S., \& V. Komlósi, A. (2014). A Rosenberg Önbecsülés Skála pszichometriai jellemzői: A pozitívan és negatívan megfogalmazott tételek múködésének sajátosságai. Pszichológia, 34(2), 149-174.

Russell, L. T., Beckmeyer, J. J., Coleman, M., \& Ganong, L. (2016). Perceived barriers to postdivorce coparenting: Differences between men and women and associations with coparenting behaviors. Family Relations, 65(3), 450-461.

Salem, P., Sandler, I., \& Wolchik, S. (2013). Taking stock of parent education in the family courts: Envisioning a public health model. Family Court Review, 51(1), 131-148.

Sanderson, D. J. (2018). Online and software programs to facilitate parenting time arrangements, support obligations, and payments. Family Advocate, 40(3), 46-48.

Sandler, I., Gunn, H., Mazza, G., Tein, J.-Y., Wolchik, S., Berkel, C., et al. (2018). Effects of a program to promote high quality parenting by divorced and separated fathers. Prevention Science, 19(4), 538-548.

Sandler, I., Miles, J., Cookston, J., \& Braver, S. (2008). Effects of father and mother parenting on children's mental health in high-and low-conflict divorces. Family Court Review, 46(2), 282-296.

Sandler, I., Wolchik, S., Mazza, G., Gunn, H., Tein, J. Y., Berkel, C., et al. (2020). Randomized effectiveness trial of the new beginnings program for divorced families with children and adolescents. Journal of Clinical Child and Adolescent Psychology, 49(1), 60-78.

Sandler, I. N., Wheeler, L. A., \& Braver, S. L. (2013). Relations of parenting quality, interparental conflict, and overnights with mental health problems of children in divorcing families with high legal conflict. Journal of Family Psychology, 27(6), 915-924.

Sbarra, D. A., \& Emery, R. E. (2005). Coparenting conflict, nonacceptance, and depression among divorced adults: results from a 12-year follow-up study of child custody mediation using multiple imputation. American Journal of Orthopsychiatry, 75(1), 63-75.

Sbarra, D. A., \& Emery, R. E. (2008). Deeper into divorce: using actor-partner analyses to explore systemic differences in coparenting conflict following custody dispute resolution. Journal of Family Psychology (Division 43), 22(1), 144-152.

Shaw, D. S., \& Emery, R. E. (1987). Parental conflict and other correlates of the adjustment of school-age children whose parents have separated. Journal of Abnormal Child Psychology, 15(2), 269-281. 
Shimkowski, J. R., \& Schrodt, P. (2012). Coparental communication as a mediator of interparental conflict and young adult children's mental well-being. Communication Monographs, 79(1), 48-71.

Smyth, B. M., \& Moloney, L. J. (2019). Post-separation parenting disputes and the many faces of high conflict: Theory and research. Australian and New Zealand Journal of Family Therapy, 40(1), 74-84.

Sodermans, A. K., Botterman, S., Havermans, N., \& Matthijs, K. (2015). Involved fathers, liberated mothers? Joint physical custody and the subjective well-being of divorced parents. Social Indicators Research, 122(1), 257-277.

Sodermans, A. K., Matthijs, K., \& Swicegood, G. (2013). Characteristics of joint physical custody families in Flanders. Demographic Research, 28(29), 821-848.

Spruijt, E., \& Duindam, V. (2009). Joint physical custody in the Netherlands and the wellbeing of children. Journal of Divorce and Remarriage, 51(1), 65-82.

Stallman, H. M., \& Ohan, J. L. (2016). Parenting style, parental adjustment, and co-parental conflict: Differential predictors of child psychosocial adjustment following divorce. Behaviour Change, 33(2), 112-126.

Stauder, A., \& Konkolÿ Thege, B. (2006). Az Észlelt Stressz Kérdőív (PSS) magyar verziójának jellemzői. Mentálhigiéné és Pszichoszomatika, 7(3), 203-216.

Symoens, S., Colman, E., \& Bracke, P. (2014). Divorce, conflict, and mental health: How the quality of intimate relationships is linked to post-divorce well-being. Journal of Applied Social Psychology, 44(3), 220-233.

Szalma, I., \& Rékai, K. (2019). Szülői felügyeleti jog, kapcsolattartás és tartásdíjfizetés a különélő magyar szülők gyakorlatában. Szociológiai Szemle, 29(4), 83-114.

Szepes, M., Czeglédi, E., Urbán, R., Horváth, K., \& Balog, P. (2014). A szülői konfliktusok észlelését mérő skála hazai alkalmazásával szerzett tapasztalatok. Mentálhigiéné és Pszichoszomatika, 15(2), 139-170.

Togliatti, M. M., Lavadera, A. L., \& Benedetto, R. D. (2011). How couples re-organized themselves following divorce: Adjustment, co-parenting and family alliance. Life Span and Disability, 14(1), 55-74.

Vanassche, S., Sodermans, A. K., Matthijs, K., \& Swicegood, G. (2013). Commuting between two parental households: The association between joint physical custody and adolescent wellbeing following divorce. Journal of Family Studies, 19(2), 139-158.

Viry, G. (2014). Coparenting and children's adjustment to divorce: The role of geographical distance from fathers. Journal of Divorce and Remarriage, 55(7), 503-526.

Visser, M., Finkenauer, C., Schoemaker, K., Kluwer, E., Rijken, R. V., Lawick, J. V., et al. (2017). I'll never forgive you: High conflict divorce, social network, and co-parenting conflicts. Journal of Child and Family Studies, 26(11), 3055-3066.

Wall, J., Needham, T., Browning, D. S., \& James, S. (1999). The ethics of relationality: The moral views of therapists engaged in marital and family therapy. Family Relations, 48(2), 139-149.

Watzlawick, P., Bavelas, J. B., \& Jackson, D. D. (2011). Pragmatics of human communication. New York: W. W. Norton and Company

Weissman, S. H., \& Cohen, R. S. (1985). The parenting alliance and adolescence. Adolescent Psychiatry, 12, 24-45.

Yelon (2021). Szülöknek, pedagógusoknak. Letöltve: 2021. március 21-én: https:/ /yelon.hu/ szuloknek/ 


\section{Köszönetnyilvánítás}

A tanulmány megírását az OTKA-PD 131671 sz. kutatási pályázat támogatta.

\section{Szerzói munkamegosztás}

A szakirodalom gyưjtését elsősorban a tanulmány első szerzője végezte, a publikációs tartalom összeállításában és a végső szöveg megalkotásában mindkét szerző azonos mértékben vett részt.

\section{Nyilatkozat érdekütközésról}

A szerzők ezúton kijelentik, hogy esetükben nem állnak fenn érdekütközések.

\section{Függelék: Ajánlott kérdőívek}

\begin{tabular}{|l|l|l|}
\hline \multicolumn{1}{|c|}{$\begin{array}{c}\text { Méróeszköz neve } \\
\text { (forrása) }\end{array}$} & $\begin{array}{c}\text { Dimenziók/alskálák } \\
\text { (tételszám) }\end{array}$ & $\begin{array}{l}\text { Hivatkozások (kutatások, amelyekben } \\
\text { a méróeszközt használták) }\end{array}$ \\
\hline Közös szülóség (együttmúködés, támogatás, konfliktus) \\
\hline $\begin{array}{l}\text { Quality of Coparental } \\
\text { Communication } \\
\text { Scale (Ahrons, 1981) }\end{array}$ & $\begin{array}{l}\text { Konfliktus (4) } \\
\text { Támogatás (6) }\end{array}$ & $\begin{array}{l}\text { Ahrons és Miller (1993); Beckmeyer } \\
\text { és munkatársai (2019); Bonach (2005); } \\
\text { Ferraro (2017); Ferraro, Lucier-Greer } \\
\text { és Oehme (2018); Hardesty, Crossman, } \\
\text { Khaw és Raffaelli (2016); Lau (2017); } \\
\text { Madden-Derdich és Leonard (2002); } \\
\text { Petren és munkatársai (2017) }\end{array}$ \\
\hline $\begin{array}{l}\text { Coparenting Interaction } \\
\text { Scale (Ahrons, 1981) }\end{array}$ & $\begin{array}{l}\text { Szülóséghez } \\
\text { kapcsolódó (10) } \\
\text { Szülőséghez nem } \\
\text { kapcsolódó (13) }\end{array}$ & $\begin{array}{l}\text { Beckmeyer és munkatársai (2014); } \\
\text { Beckmeyer, Ganong, Coleman } \\
\text { és Markham (2017); Beckmeyer } \\
\text { és munkatársai (2019); Hardesty } \\
\text { és munkatársai (2016); Lau (2017); } \\
\text { Madden-Derdich és Leonard (2002); } \\
\text { Russell, Beckmeyer, Coleman }\end{array}$ \\
& és Ganong (2016) \\
\hline $\begin{array}{l}\text { Coparenting } \\
\text { Relationship Scale } \\
\text { (Feinberg és mtsai, } \\
\text { 2012)** }\end{array}$ & $\begin{array}{l}\text { Egyetértés (4) } \\
\text { Közelség (5) } \\
\text { A gyermek } \\
\text { konfliktusnak } \\
\text { kitettsége (5) } \\
\text { Támogatás (6) } \\
\text { Aláásás (6) } \\
\text { A partner elismerése } \\
\text { szülóként (7) } \\
\text { Munkamegosztás (2) }\end{array}$ & $\begin{array}{l}\text { Galovan és Schramm (2017); } \\
\text { Lamela és munkatársai (2016); } \\
\text { McDaniel, Teti és Feinberg (2017) }\end{array}$ \\
\hline
\end{tabular}




\begin{tabular}{|c|c|c|}
\hline $\begin{array}{l}\text { Méróeszköz neve } \\
\text { (forrása) }\end{array}$ & $\begin{array}{c}\text { Dimenziók/alskálák } \\
\text { (tételszám) }\end{array}$ & $\begin{array}{c}\text { Hivatkozások (kutatások, amelyekben } \\
\text { a méróeszközt használták) }\end{array}$ \\
\hline $\begin{array}{l}\text { Parenting Alliance } \\
\text { Inventory (Abidin \& } \\
\text { Brunner, 1995) }\end{array}$ & (20) & $\begin{array}{l}\text { Becher és munkatársai (2019); } \\
\text { Lamela és Figueiredo (2011) }\end{array}$ \\
\hline $\begin{array}{l}\text { Coparenting } \\
\text { Questionnaire (Margolin } \\
\text { és mtsai, 2001) }\end{array}$ & $\begin{array}{l}\text { Együttmúködés (5) } \\
\text { Konfliktus (5) } \\
\text { Trianguláció (4) }\end{array}$ & $\begin{array}{l}\text { Beckmeyer és munkatársai (2014); } \\
\text { Beckmeyer és munkatársai (2017); Lau } \\
\text { (2017); Russell és munkatársai (2016) }\end{array}$ \\
\hline $\begin{array}{l}\text { Measure of Co-Parenting } \\
\text { Alliance (Dumka, 2002) }\end{array}$ & $(13)$ & $\begin{array}{l}\text { Cookston, Braver, Griffin, } \\
\text { De Lusé és Miles (2007) }\end{array}$ \\
\hline $\begin{array}{l}\text { Supportive Coparenting } \\
\text { Scale (Weissman \& } \\
\text { Cohen, 1985) }\end{array}$ & (6) & Kamp Dush és munkatársai (2011) \\
\hline $\begin{array}{l}\text { Experiences with } \\
\text { Coparenting Scale } \\
\text { (Beckmeyer és mtsai, }_{2017)^{* *}}\end{array}$ & (11) & \\
\hline $\begin{array}{l}\text { Daily Coparenting Scale } \\
\text { (McDaniel és mtsai, } \\
\text { 2017)** }\end{array}$ & $(10)$ & \\
\hline \multicolumn{3}{|l|}{ Konfliktus } \\
\hline $\begin{array}{l}\text { Children's Perception of } \\
\text { Interparental Conflict } \\
\text { (Grych és mtsai, 1992) }^{*}\end{array}$ & $\begin{array}{l}\text { Gyakoriság (6) } \\
\text { Intenzitás (7) } \\
\text { Megoldás (6) } \\
\text { Tartalom (4) } \\
\text { Észlelt fenyegetés (6) } \\
\text { Megküzdés } \\
\text { hatékonysága (6) } \\
\text { Önvád (5) } \\
\text { Trianguláció (8) }\end{array}$ & $\begin{array}{l}\text { Becher és munkatársai (2019); Cookston } \\
\text { és munkatársai (2007); Drapeau, Gagné, } \\
\text { Saint-Jacques, Lépine és Ivers (2009); } \\
\text { Elam, Sandler, Wolchik és Tein (2016); } \\
\text { Elam, Sandler, Wolchik, Tein és Rogers } \\
\text { (2019); Modecki, Hagan, Sandler } \\
\text { és Wolchik (2015); Sandler, Miles, } \\
\text { Cookston és Braver (2008); Sandler, } \\
\text { Wheeler és Braver (2013); Spruijt } \\
\text { és Duindam (2009); Szepes, Czeglédi, } \\
\underline{\text { Urbán, Horváth és Balog (2014) }}\end{array}$ \\
\hline $\begin{array}{l}\text { Acrimony Scale } \\
\text { (Shaw \& Emery, 1987) }\end{array}$ & (25) & $\begin{array}{l}\text { Emery és munkatársai }(2001) ; \\
\text { Sbarra és Emery }(2005,2008) ; \\
\text { Stallman és Ohan }(2016)\end{array}$ \\
\hline $\begin{array}{l}\text { Conflicts and Problem- } \\
\text { Solving Scales } \\
(\text { Kerig, 1996)** }\end{array}$ & $\begin{array}{l}\text { Gyakoriság (válás } \\
\text { előtt és után) (4) } \\
\text { Konfliktuskezelési } \\
\text { stratégiák: } \\
\text { Együttmúködés (6) } \\
\text { Elkerülés (10) } \\
\text { Időhúzás (7) } \\
\text { Verbális agresszió (8) } \\
\text { Fizikai agresszió (7) } \\
\text { Gyermek bevonása (5) }\end{array}$ & Galovan és Schramm (2017) \\
\hline
\end{tabular}




\begin{tabular}{|c|c|c|}
\hline $\begin{array}{l}\text { Mérőeszköz neve } \\
\text { (forrása) }\end{array}$ & $\begin{array}{c}\text { Dimenziók/alskálák } \\
\text { (tételszám) }\end{array}$ & $\begin{array}{c}\text { Hivatkozások (kutatások, amelyekben } \\
\text { a méróeszközt használták) }\end{array}$ \\
\hline $\begin{array}{l}\text { Caught Between Parents } \\
\text { Scale (Buchanan és } \\
\text { mtsai, 1991) }\end{array}$ & (7) & Lau (2017) \\
\hline $\begin{array}{l}\text { Overt Hostility Scale } \\
\text { (Porter \& O'Leary, 1980) }\end{array}$ & (20) & Owen és Rhoades (2012) \\
\hline \multicolumn{3}{|l|}{ Gyermekek jólléte } \\
\hline $\begin{array}{l}\text { Strengths and Difficulties } \\
\text { Questionnaire } \\
\text { (Goodman, 1997)* }\end{array}$ & $\begin{array}{l}\text { Érzelmi tünetek (5) } \\
\text { Viselkedési } \\
\text { problémák (5) } \\
\text { Hiperaktivitás (5) } \\
\text { Kortárskapcsolati } \\
\text { problémák (5) } \\
\text { Proszociális } \\
\text { viselkedés (5) }\end{array}$ & $\begin{array}{l}\text { Birkás, Lakatos, Tóth és Gervai (2008); } \\
\text { Keating, Sharry, Murphy, Rooney } \\
\text { és Carr (2016); Lamela és munkatársai } \\
\text { (2016); Lau (2017); Lucas, Nicholson } \\
\text { és Erbas (2013); Sandler és munkatársai } \\
\text { (2013); Stallman és Ohan (2016); } \\
\text { Viry (2014) }\end{array}$ \\
\hline $\begin{array}{l}\text { Child Behavior Checklist } \\
(\text { Achenbach, 1991)* }\end{array}$ & $\begin{array}{l}\text { Internalizált } \\
\text { problémák (31) } \\
\text { Externalizált } \\
\text { problémák (33) }\end{array}$ & $\begin{array}{l}\text { Drapeau és munkatársai (2009); } \\
\text { Dunn, O'Connor és Cheng (2005); } \\
\text { Elam és munkatársai (2016); Elam és } \\
\text { munkatársai (2019); Rózsa, Gádoros } \\
\text { és Kő (1999); Sandler és munkatársai } \\
\text { (2018); Sandler és munkatársai (2008) }\end{array}$ \\
\hline $\begin{array}{l}\text { Rosenberg Self-Esteem } \\
\text { Scale (Rosenberg, 1965)* }\end{array}$ & (10) & $\begin{array}{l}\text { Bastaits és Mortelmans (2016); Bastaits, } \\
\text { Ponnet és Mortelmans (2012, 2014); } \\
\text { Lau (2017); Rózsa \& V. Komlósi (2014) }\end{array}$ \\
\hline $\begin{array}{l}\text { Children's Depression } \\
\text { Inventory (Kovacs, 1981) }\end{array}$ & $(27)$ & $\begin{array}{l}\text { Elam és munkatársai (2016); } \\
\text { Sandler és munkatársai (2008) }\end{array}$ \\
\hline \multicolumn{3}{|l|}{ Szüloók jólléte } \\
\hline $\begin{array}{l}\text { Satisfaction with Life } \\
\text { Scale (Diener, Emmons, } \\
\text { Larsen, \& Griffin, 1985)* }\end{array}$ & (5) & $\begin{array}{l}\text { Lamela és munkatársai (2016); Martos, } \\
\text { Sallay, Désfalvi, Szabó és Ittzés (2014) }\end{array}$ \\
\hline $\begin{array}{l}\text { Rosenberg Self-Esteem } \\
\text { Scale (Rosenberg, 1965)* }\end{array}$ & $(10)$ & $\begin{array}{l}\text { Rózsa \& V. Komlósi (2014); } \\
\text { Sodermans, Botterman, Havermans } \\
\text { és Matthijs (2015) }\end{array}$ \\
\hline $\begin{array}{l}\text { Cantril ladder } \\
\text { (Cantril, 1965) }\end{array}$ & $(1)$ & $\begin{array}{l}\text { Sodermans és munkatársai (2015); } \\
\text { Spruijt és Duindam (2009) }\end{array}$ \\
\hline $\begin{array}{l}\text { Perceived Stress Scale } \\
\text { (Cohen, Kamarck, \& } \\
\text { Mermelstein, 1983)* }\end{array}$ & $(14)$ & $\begin{array}{l}\text { Ferraro és munkatársai (2018); } \\
\text { Petren és munkatársai (2017); } \\
\text { Stauder és Konkolÿ Thege (2006) }\end{array}$ \\
\hline
\end{tabular}

Megjegyzés: * validált magyar verzió; ** a magyar verzió validálása folyamatban. A magyar nyelven is elérhető kérdőívek forrását aláhúzással emeltük ki. 


\title{
Coparenting after divorce: A literature review
}

\author{
PILINSZKI, ATTILA - GYETVAI, ANNA
}

This study aims to provide a review of the main research findings on coparenting after divorce, parental cooperation and conflicts. The concept of coparenting refers to the interactions and relationship between parents which must be maintained even after divorce. In our paper, we cover some aspects of coparenting (parental communication, mutual support, undermining, conflicts and conflict management) and the most common background variables in the relevant studies (divorce process, type of custody). The consequences of divorce and the success of adapting to the new situation are of significant importance for both parents and children, however, the topic of coparenting after divorce appears in few Hungarian publications. With the present study, we aim to fill this gap and to initialize domestic research on the issue. Based on the examined literature, it can be stated that the formation of a new state of equilibrium after the dissolution of the relationship is of great importance, as the quality of coparenting is related to the well-being of children and adults as well. Some of the relevant empirical literature relates to preventive training programs aimed at improving the quality of coparenting after divorce. We, therefore, mention several such programs, briefly describing their specifics and related empirical results. In conclusion, due to the complex topic of coparenting after divorce and the often different narratives of parents, it is justified to choose a dyadic research approach that can capture this complexity. We would also like to draw attention to the fact that there is a lack of educational programs for divorced parents in Hungary, although it would be important to develop and disseminate them widely for the well-being of parents and children.

Keywords: coparenting, divorce, cooperation, wellbeing of children

A cikk a Creative Commons Attribution 4.0 International License (https:/ / creativecommons.org/ licenses/by/4.0/) feltételei szerint publikált Open Access közlemény, melynek szellemében a cikk bármilyen médiumban szabadon felhasználható, megosztható és újraközölhető, feltéve, hogy az eredeti szerző és a közlés helye, illetve a CC License linkje és az esetlegesen végrehajtott módosítások feltüntetésre kerülnek. (SID_1) 